\title{
AUTHORIAL SIGNATURES IN
}

\section{LATE MEDIEVAL WORKS}

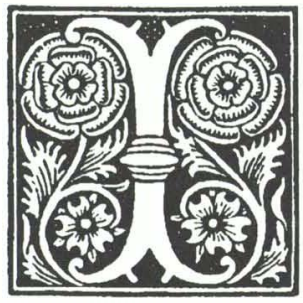

$\mathrm{n}$ the two preceding chapters, we have examined the paratextual presentation of authors: those cases in which their names appeared in an incipit and explicit, on the title page and in the colophon, and those cases in which their images figured in their books. In this chapter, I enter the confines of the literary work itself with a study of writers' signatures, those marks which represent one of the most obvious signs of textual appropriation and authorial self-consciousness, the visible and supposedly definitive "proof" of the origin and authenticity of a work (Sala, 118). In fact, in late medieval and early Renaissance Europe, a link can be drawn between the emergence of portraits, including self-portraits, and the vogue of signatures, as the visual translation of Molinet's name in the illustrations analyzed above exemplifies. ${ }^{1}$

I do not treat actual autograph signatures here, because, with the gradual privileging of print following the invention of movable type, they had more of an impact on the juridical and even the art world than on the literary world. Nevertheless, the history of autograph signatures underpins my following remarks in a crucial way, because it uncovers an important relationship between the displacement at this time of medieval symbolic imagery by representational realism and a changing, more personalized concept of identity (Fraenkel, 11). This association was translated most concretely perhaps into Henry II's Ordonnance of Fontainebleau in 1554, which invested not only the written word but the written name with a new legal power by requiring that all notarized acts, contracts, legal obligations, receipts, and private transactions be signed.

1. Fraenkel, 275 , calls attention to the association between the first realist portrait of a French king, John the Good, and the fact that he was the first monarch to sign his own letters of patent. See also Chastel, 8-9, who speaks of this relationship in Northern Renaissance Europe, and Sala, 119-27. 
I focus here on what one might call textual signatures, the incorporation of writers' names and identities into their texts in the late medieval period. By the nature of their very personalized formulations, textual signatures came close to functioning like autograph signatures. Moreover, unlike the advertisement of an author's name on title page and colophon-commonly subject to distortion by forces beyond the writer's jurisdiction - the textual encoding of authorial identities represented the surest means writers had to publicize and control their association with their works. If, at this time, a writer transformed a piece of paper into a juridical act by signing it, as Fraenkel argues (12), then it is equally true that the coupling of an author's textual signature with the advertisement of his legalized control over his publications both authorized and validated writings in a previously unknown way. What is important here is not the actual use of textual signatures, which dates back at least to the Latin Middle Ages, but the way they are reinforced by paratextual material and the fact that authors' changing signatures reflect a more defensive literary consciousness than that of their predecessors. ${ }^{2}$

Textual signatures took on a variety of forms, and medieval authors often presented them playfully. ${ }^{3}$ Simple proper names that were directly accessible to the reader figured in the early medieval works of Chrétien de Troyes, Marie de France, Béroul, Thomas, and Jean de Meun, who identified both himself and his predecessor, Guillaume de Lorris, in the well-known passage near the midpoint of the two parts of the Roman de la rose. ${ }^{4}$ But textual signatures could be ambiguous as well. Sometimes the reader had to rearrange, reconstruct, or re-view the letters of a name in order to decipher it properly, a phenomenon that had to do with the tastes of the court. Guillaume de Machaut, who named himself directly in his Jugement dou roy de Navarre and the Prise d'Alexandrie, more often followed the vogue set by Nicole de Margival in the Dit de la panthère $d^{\prime}$ amours (ca. 1300) and in nearly all his other dits: punctuation of the text with anagrammic signatures that were not always easy to decode. The signatures extensively adopted by Jean Froissart were equally difficult to

2. It is perhaps no coincidence that many vernacular authors of the fifteenth century, including Alain Chartier, André de la Vigne, and Jean Lemaire, were royal secretaries who often signed documents for their patrons. They may have developed a particularly acute sense of the relationship between the signature and one's identity, which by 1554 would be extended to French society as a whole.

3. For details on the different kinds of signatures, see Kooper, and the Revue de l' Art 26 (1974): 8-54. See also Kane, 53-57, who investigates the fourteenth-century convention in which authors of dream-vision poems signed their work by naming the dreamer-narrator after themselves.

4. For an excellent discussion of these and other earlier signatures see Huot, From Song to Book, and Dragonetti's "Noms," 13-40. 
unravel. ${ }^{5}$ In fact, many anagrams, such as the one that appears at the end of the Bestiaire d'amour rimé, remain unsolved because of their complicated nature. ${ }^{6}$ Punning signatures, which worked simultaneously in two directions, could be ambiguous as well, though in a different sense. Referring outward and identifying the writer, the punning name served to mark the text as his creation. At the same time, its playful expression drew attention away from the extratextual, proper name of the text's creator to other, more common meanings of the name which were associated with the language of the text in such a way that the reader could overlook or misunderstand the author's proper name (Kamuf, 12-13).

Maintaining the ambiguity of both the name itself and its potential meanings was, however, the ultimate goal of many authors, who sought to delight their audience with onomastic games. Potentially irretrievable, these punning signatures, such as those which Rutebeuf incorporated into many of his poems (CEuvres, ed. Faral and Bastin, 1:34-35), were nevertheless more accessible than their cryptogrammic counterparts, because, like acrostic signatures, they retained the order of the letters in the proper name. But success in understanding these signatures depended upon the mode of transmission: the decoding of punning names often necessitated oral delivery, whereas acrostic signatures were retrievable only by a visual reception of the text.

These two forms of signatures, metaphorical and acrostic, appeared most commonly in the works of late medieval and early Renaissance French authors, who, more than any other literary generation, were preoccupied with names and name games (Rigolot, Poétique, 27). For it is not writers' signatures per se that are of interest here so much as the striking modifications late medieval authors made in their signatures over the course of their careers. ' How do we explain why the acrostic device or the straightforward, capitalized name tended to replace the pun-

5. See Hoepffner, "Anagramme"; Looze, "Mon nom trouveras"; and Cartier.

6. Huot, From Song to Book, 164, associates the late thirteenth-century, early fourteenthcentury delight in anagrams with the development of a more writerly mode of poetics, whereas Cartier, 100, suggests that anagrams reflected the discretion required by courtly love codes.

7. For examples of earlier punning signatures, see the works of Colin Muset and Rutebeuf, Jakemes's Roman du castelain de Couci (see Huot, From Song to Book, 117-34), Tibaut's Roman de la poire (see Marchello-Nizia ed., xxiv-xxxi), and the works of Eustache Deschamps (see Hoepffner ed., 3:381, 4:114). For earlier examples of acrostic signatures, see Guillaume de Deguileville's Pelerinage de la vie humaine (see Kane, 54), Deschamps (Hoepffner ed., 4:222, 5:164), and François Villon's Ballade pour prier Notre Dame, Ballade à s'amie, Ballade de la Grosse Margot, Ballade des contre-vérités, Débat du cueur et du corps, and Balladede bon conseil (see Uitti, "Villon's Poetics"). See also Gros, 49-61; Minnis, Theory, 170; Quilligan, Language of Allegory, 164; Smalley, 135; and Trapp. 
name as the more favored form of textual signature at this time? I argue that these signatures represent another example of writers' changing perceptions of themselves and of their publics at a time when the economics of the print culture threatened their literary reputations. As vernacular authors became more concerned about the need to maintain control over their own words, they became attuned to the importance of affixing their names to their texts in a more immediately recognizable fashion. This shift to more easily decipherable names coincided with a general movement toward the literal and a privileging of the written word that came with the advent of print. ${ }^{8}$ In several key cases, the aggressive behavior of Parisian publishers caught up in the book-trade competition precipitated this shift. Although they often appropriated works without writers' authorization, combined them with other texts in a manner unacceptable to the author, and failed to publicize authors' names in the paratext, publishers rarely tampered with authors' signatures once these were incorporated into the texts. For example, even though publishers never acknowledged Molinet's authorship in their editions of his Temple de Mars, they never altered his punning signature at the end of the text. Whereas Vérard had inappropriately taken and published Bouchet's Regnars traversant, wrongly attributed it to a more famous writer, and eliminated some words while appending another's to it, he did maintain Bouchet's acrostic signature. Thus, there appears to have been a reluctance on the part of publishers to change the author's textual signature.

Paratextual material placed between title pages and texts, however, such as the prologues in which writers often identified themselves, could be unreliable vehicles for authorial signatures, especially in manuscript form (although their incorporation into the printed book eventually provided a more stable space for self-identification). Translations represent another example of how authors' textual signatures could disappear through publishing changes. And evidence shows that at least one printer, the infamous Michel Le Noir, dared to alter an author's signature after the poet had integrated it into his text.

The changing poet-patron relationship relates directly to these modifications. Charles Sala, in speaking of artists, has recognized that the act of signing a work, as a claim of intellectual proprietorship, led to a sense of autonomy and to the establishment of new rules of social conduct between patron and author: the created work is linked definitively to a per-

8. See Zumthor, Masque, 81-82, who describes the movement of allegory toward the literal, and Foucault, Order of Things, 38, who, among others, speaks of the privileging of writing with the advent of print. Wilson, 54-59, argues that the movement from Rutebeuf's punning signatures to Villon's acrostic signatures reflects the change from a hearing to a reading public. See also Gros, 51 . 
sonality, or at least a name, and to the talent of an author, who thereby stands outside the protective shadow of tradition (121). I argue that the growing effort of late medieval vernacular writers to spell out their own names unambiguously when incorporating them into their texts reflects their gradual refusal to hide behind the names of their patrons and parallels their search for more self-promotional opportunities and for greater validation as literary creators. This move is all the more evident in the context of increasing paratextual advertisement of the author. For there was an inherent contradiction between the manifest way in which authors had come to integrate their patrons' names into their texts and the more modest fashion in which they identified themselves. One can see the fundamental ambiguity of a work written for the sake of an "idealized Other" by a poet increasingly conscious of his own identity and artistic role. ${ }^{9}$ If, as Laurence de Looze has so convincingly argued, the use of anagrammic signatures presupposed that an initiated audience already knew the author's name ("Mon nom trouveras," 550-52), then the gradual adoption of more straightforward signatures suggests that authors knew they could no longer assume such complicity between poet and public. The nature of their audience was changing with the advent of print. Vernacular writers' more publicly conscious appropriation of their works in this late medieval period through the adoption of more accessible textual signatures represents yet another sign of their increasingly defensive posture as authors and their more attuned sense of self-importance and proprietorship in the face of growing market pressures. These developments accompanied their growing control of book reproduction and their greater paratextual visibility, as I have discussed above, as well as the gradual separation of their own voices from their protagonists', as I argue in the final chapter.

With Jean Molinet, the reader witnesses this transition from a playful signature, which typified a court poet's attempt to please the ludic instincts of his patron and associates, to the adoption of a more straightforward name, whose increasing appearance in texts written after the advent of print suggests the existence of a new impulse to lay claim to one's words and to ensure a less elite readership more immediate access to the author. In many of Molinet's works, especially his earlier, more traditional writings, the reader discovers one of several versions of his punning signature..$^{10}$ The similarity in pronunciation at the time between

9. See Starobinski, 17, who adopts this term, and Le Coq, "Cadre et rebord," 20, who offers a similar reflection about painters.

10. Of the forty-five "circumstantial" poems edited by Dupire in volume 1 of Molinet's Faictz et dictz, fifteen bear his signature, including his Complainte de Grèce (1464), Trosne d'honneur (after June 1467), Temple de Mars (after 1475), Chapellet des dames (after 1478), Res- 
his name and a small "moulin" or "moulinet," led the rhétoriqueur to create an extended metaphorical comparison between the workings of a mill in producing flour and those of the poet Molinet making verse. ${ }^{11}$ Instead of incorporating into his text his capitalized proper name, limiting its significance to the identification of his person, Molinet reified his name and verbally metamorphosed himself into a mill, whose workings resembled the poetic process itself. The process of creating verse was thereby recalled each time the writer signed his text, in a gesture that recalls Rutebeuf's name games (see Wilson, 53). While other contemporary poets, such as André de La Vigne and Guillaume Cretin, adopted a punning signature to identify their works, it was Molinet who most successfully exploited his metaphorical name.

Toward the end of his career, though, Molinet replaced this punning signature with his more straightforward name. The underlying explanation of this remarkable change may possibly be connected with the publication history of his Art de rhétorique, which offers a striking example of the potential dangers of authorial self-naming in a prefatory rather than a textual manuscript space. Although Molinet punningly refers to himself when addressing his patron in the manuscript versions of the work, the dedication was manipulated in its later printed forms in such a way that his authorship disappeared. This development coincides with the adoption of more accessible and more reliably placed signatures by the writer, suggesting that Molinet had come to realize the importance of maintaining control over the reproduction of his name and his works, especially those which might circulate beyond the confines of the court for which they were originally composed.

Written between 1482 and 1492, the poetic treatise contained in the Art de rhétorique provides the very rules for creating verse that form part of the image to which Molinet's punning signature gives rise: namely, the rules that make the rhétoriqueur's poetic mill function. ${ }^{12}$ The reader finds the symbol of his name, the poetry mill, literally and fully decoded in the body of the Art de rhétorique. The relationship Molinet so masterfully develops between his proper name and the text in which he inscribes it not

source du petit peuple (after May 1481), L'arbre de Bourgogne (after April 1486), and Voyage de Naples (after September 1496). After 1496, Molinet tended to compose briefer works, perhaps because his eyesight was failing; his signature is found in several short poems (36184 vv.) written between 1497 and 1502. In volume 2, which contains religious, parodic, and personal poems as well as some prose works, six poems bear Molinet's signature; in addition, there are a good many letters, exchanged with his contemporaries, in which his name is played upon at length.

11. Some of the following remarks appear in different form in my "Eveill" 15-35.

12. Appendix 4 below provides a list of the various versions of this work. 
only reinforces the text's meaning but also plays a major role in generating it. ${ }^{13}$

The incipit announcement of the author's name in the fifteenthcentury manuscript of the Art de rhétorique (B.N., ms. f.fr. 2159) is reinforced by the appearance of Molinet's punning signature in its dedicatory prologue (my emphasis): “De laquele rethorique, mon tres honnorés sire, se c'est chose qui gaires vaille: vous prenderez en gré s'il vous plaist tant la fleur comme la farine tele que vostre tres humble et petit $\mathrm{mo}$ linet a sceut tourner entre ses meules" (Please accept willingly this rhetoric, my very honorable lord, if it is worthy, both the wheat and the flour, such as your very humble and little mill [Molinet] was able to turn between its millstones) (fol. iiv). ${ }^{14}$ Yet, just as Vérard in 1493 and other publishers after him failed to announce the author's name on the title page of their editions of the Art de rhétorique, so too the punning signature that Molinet had incorporated into the dedication of his work is missing in those versions. Molinet's name had disappeared because of its association with a patron in a manuscript dedicatory prologue, which had been removed in those editions printed for a more general public. Like the signature that artists might originally place on the frames of their paintings, a signature that could be lost through replacement of the frame, Molinet's identity was eliminated when his work was "packaged" in a different way. ${ }^{15}$ As a result, the copies that the largest number of readers (those who were not very familiar with the poet) would have purchased were copies that furnished no details about the author of the Art de rhétorique.

Two vellum copies of this edition, however, do feature a dedication, which is partially derived from Molinet's manuscript prologue (Paris, B.N., Vélins 577; London, B.L., IB.41139). ${ }^{16}$ The following passage replaces the one containing Molinet's punning signature (my emphasis):

13. Rigolot, Poétique, 12ff., discusses the relationship between the phonics, graphics, and ideology of the name. See also Gros, who discusses the graphics of the name in late medieval Marial poetry.

14. The same dedicatory prologue appears in the sixteenth-century manuscript of the work (B.N., ms. f.fr. 2375 [5]).

15. The signature in art, examined by Chastel and others in a series of articles on "L'art de la signature" in the Revue de l'Art 26 (1974): 8-54, offers a number of interesting points of comparison with signatures in literature. If the canvas finds its counterpart in the literary text, the picture frame can be equated with the paratext: the prologue, title page, and colophon. Le Coq, "Cadre et rebord," 16, makes a comparison between the picture frame and the manuscript margin. See also Fraenkel, 168-74, and Adams, who draws a fascinating parallel to the issues raised here in her discussion of signatures in the seventeenthcentury world of Dutch artists.

16. For a comparison of the printed and manuscript prologues, see Langlois's edition of Molinet's Art de rhétorique in Recueil d'Arts, 214-15. 
"vostre treshumble et tresobeissant subject et serviteur Henry de Croy" (fol. ai") (your very humble and very obedient subject and servant Henry de Croy). ${ }^{17}$ Because none of the other surviving printed editions of the Art de rhétorique bears Molinet's name, scholars mistakenly attributed the treatise to Henry de Croy until the late nineteenth century (Byvanck, 8o, n. 2).

Molinet's authorship of his text is manipulated in yet another way in the transition from manuscript to print. At one point in Vérard's edition of the Art de rhétorique, there appears a reference to the poet, absent in the manuscript. In furnishing examples of the "rime batelée" from his own works without identifying himself as author, Molinet obviously assumed that his dedicatee would know he had written them: "De ceste nouvelle mode sont coulourez la Complainte de Gresse, le Trosne d'honneur, le Temple de Mars, les ouvrages de la pucelle et la Resource du petit peuple" (With this new mode are embellished the Complaintede Grèce, the Trosne d'honneur, the Temple de Mars, the [Naufrage] de la pucelle, and the Ressource du petit peuple) (fol. b iiv). In Vérard's printed edition, however, the following sentence is added at this point: "Et en a esté inventeur maistre Jehan Molinet de Valenciennes" (And Master Jean Molinet of Valenciennes was the inventor of this) (fol. $\mathrm{b}$ ii ${ }^{\nu}$ ). This edition indicates that the publisher knew his readers would not automatically associate Molinet with the listed works. Although Vérard explicitly named Molinet as inventor of the "rimes batelées," the author did not receive credit for composing the entire treatise of which these references form a small part.

One cannot know for sure if Vérard was aware that Molinet was the author of the Art de rhétorique or if Henry de Croy was solely responsible for replacing Molinet's name in the dedication with his own. But Vérard's unauthorized publication of Jean Bouchet's Regnars traversant just ten years later suggests he was involved in these earlier modifications, which may have been considered "legitimate" in the early stages of printing by publishers (see also Langlois, ed., Recueil d'Arts, lxiv, n. 2). Nevertheless, the fact that the edition designated Molinet as the inventor of "rimes batelées" reveals that both Croy and Vérard knew at the very least that the poet had an established reputation.

By the time Jean Trepperel printed the second known edition of the

17. Langlois, ed., Recueil d'Arts, lxi-lxiii, pointing out the careless mistakes in the Vérard edition, suggests that Molinet might have originally dedicated the manuscript treatise to Philippe de Croy, or even to his son Henry de Croy, who then appropriated it as his own in the printed edition and dedicated it to the French king. The Croys, known as supporters of the arts, were then an important family in the Burgundian region through the marriage in 1455 of the seigneur de Croy with Jacqueline de Luxembourg. 
Art de rhétorique, six years later in May 1499, neither Molinet's nor Henry de Croy's name was associated with the work. Like the paper copies of Vérard's edition, which probably served as Trepperel's source, no dedication and therefore no authorial identification whatsoever figured in this or subsequent editions.

Thus, the identity of the writer of the Art de rhétorique disappeared in the transition from manuscript to print, having been replaced in the prologue of Vérard's vellum copies by the bogus authorship of Henry de Croy or eliminated altogether in the paper copies. This eradication of the true author's identity occurred because Molinet had not integrated his name into the text of the Art de rhétorique and because his writing had become a marketable imprint outside the manuscript community for which he had originally produced it.

Another feature that contributes to the deformation of the Art de rhétorique text is a passage, added in the later printed versions, that identifies the French king. Whereas the original dedicatee of the Art de rhétorique remained unnamed in the manuscript prologue, Charles VIII, who had had no connection with Molinet's commission to write a guide to poetic writing, is named in all the printed editions of the work in a rondeau-acrostic that spells out CHARLES DE VALOIS on the final folio. So that readers would not fail to recognize his name, verses following the passage direct them to reconstruct it:

Comme tresor florissant par nature, Hault triumphant par eternelle fabrique,

A vous honneur, trescrestien roy puissant, Resplendissant soubz science auctentique, Louer on doit tel sens tant magnifique En rethorique quant on y prent pasture; Sens est parfaict adjoustant sa musique, Dont fault venir aulx termes contestant Equivoquant, congnoissant la droicture Comme tresor, etc.

Vault il pas mieulx adjouster la replique A composer quant l'engin s'y procure L'euvre parfaicte? Le cas est congnoissant. O quel renom quant sens a bien s'applique! Yeulx regardez, fuyez la chose inique Sans repugner les termes de droicture Comme tresor, etc. 
Visez, musez, de hault en bas lisez

Nom et surnom du Roy vous trouverrez, Charles huitiesme que Dieu doint bonne vie Et en la fin la grant joie parfournie. (fol. $\left.b v^{v}\right)$

Examine, study, read from top to bottom, and you will find the name and surname of the king, Charles VIII. May God grant him good life and in the end great, fulfilling joy.

The adoption of the acrostic form here allows for a two-dimensional homage to the French king. For the vertical staging of Charles VIII's name gives rise to a horizontal celebration of his virtues. Described as a perfect work, a resplendent treasure of nature, the king is lauded for his magnificent power, knowledge, justice, and understanding. This onomastic strategy, which many of Molinet's contemporaries would eventually adopt to publicize their own identities, graphically associates the name and fame of the person glorified. ${ }^{18}$

Absent from both manuscript versions of the Art de rhétorique, because the work was not originally dedicated to the French monarch, these verses, presumably added by Vérard (or Croy?), doubtless served as thanks for (or anticipation of) Charles VIII's patronage. The CHARLES DE VALOIS acrostic thereby functioned as a self-reflecting mirror for Vérard's or Croy's, but not Molinet's, potential benefactor. Moreover, because it appeared in all subsequent publications of the work, the acrostic and the horizontal message generated by it presented the king's name and image as a model for each book purchaser. In replacing the names of both author and patron of the original work with others that more appropriately met his personal capitalistic needs, the publisher Vérard had in essence reappropriated Molinet's work and reformulated the dynamics of the text. What had originally served to teach a noble about the art of writing love poetry had become an excuse to praise another noble.

Molinet had often faithfully accorded textual publicity to his aristocratic sponsors through the use of acrostic-like forms, such as his homage to Philip the Good in the Trosne d'honneur (1467) or to Mary of Burgundy in the Chappellet des dames (1478) (Scheidegger, 214-25). But he had balanced this focus on his patrons with self-references, albeit less imperious ones, through the incorporation of his nameinto these verses (my emphasis): ${ }^{19}$

18. Rigolot, Poétique, 31-32, discusses this association in another context.

19. See Machaut's earlier use of anagrams for both his own and his patron's name in works such as the Fontaine amoureuse (Jean de Berry) and Confort d'ami (Charles de Navarre) (see Hoepffner, "Anagramme," 404-7) or Froissart's Espinette amoureuse (Fourrier ed.), 


\section{Changing Authorial Signatures}

Du vent tel que Dieu donna

Au limeur de gros limage,

Mon gros molinet tourna

Et rima ce gros rimage.

(Trosne, 1:58, vv. 40-43)

D'ung verd champ ou le mol lin n'est

En soufflant tant de vent widasmes

Qu'en tournant nostre molinet

Molut le Chappellet des dames.

(Chappellet, 1:126, vv. 21-24)

The appropriation of Molinet's Art de rhétorique by someone other than the true author and the addition to it of verses paying homage to a different patron represent one more example of why vernacular writers resorted to self-defense in the early years of the sixteenth century. Like the altered illustrations decorating the Art de rhétorique editions, the presence or absence of Molinet's textual signature in these versions reflects the ambiguous status of authorship at the end of the fifteenth century. The text and its subject, which was often an aristocratic figure, were more valued and publicized than the originator.

But this situation was to change. The growing advertisement of Molinet's authorship on the title page and in the images associated with a later work, the Roman de la rose moralisé, published by the very same Vérard around 1500, is reinforced by the author's textual self-inscription, which reappeared in all editions of the work. ${ }^{20}$ The final verses, which remained firmly anchored to the text, furnish evidence of how Molinet artfully wove the multiple meanings of his proper name into the metaphorical texture of his poetic creation (my emphasis):

L'an quinze cent tournay molin au vent, Et le couvent d'amours ouvri ma baille, Chargiet de grain [l]'engranay telement Que rudement, a mon entendement

Prins du fourment la fleur que je vous baille,

where both his and his lady's name (Marguerite) are integrated together into verses 338589 . These combinations are, however, much more difficult to decipher than those found in the poets examined here.

20. Appendix 4 below provides a bibliographical listing for this work. 
Rués la paille, aprez qui maint sot baille A la happaille, et loing du jardinet

Le monnoier doibt avoir son molin net. ${ }^{21}$

In the year 1500 I turned the windmill and the convent of love initiated my servitude. Laden with grain I filled it with so much seed that crudely, according to my understanding, I took from the wheat the flour that I give to you, having discarded the chaff, whereas most fools offer the chaff. And far from the little garden, the miller must keep his mill clean.

Even though the designation of Philippe de Clèves as dedicatee of the manuscript version of the Roman de la rose moralisé is absent from the printed editions of the work, Molinet's name figures prominently in both, for he had originally integrated it into the last lines of his text. While it is not possible to ascertain whether Molinet was actually reacting to the omission of his authorship in the Parisian publications of the Art de rhétorique seven years earlier, evidence suggests that his selfperception and attitude toward printed works had undergone a dramatic change by 1500 . Molinet's decision to publish some of his works accompanies a growing tendency to sign his writings straightforwardly.

An examination of Molinet's other signed texts reveals an interesting pattern. The metaphorical signatures of those works written before 1493 focus on the object of the "moulin" itself, as the poem is "mollu d'un gros mollinet" (ground by a large mill) (Complainte de Grèce [1464], 1:26, v. 24). Sometimes the "moulinet" is possessed by the author, instead of representing the author, as it lacks or receives wind from God. ${ }^{22}$ Or it can potentially be owned by others: "Chascun n'a pas son molin net" (Everyone does not keep his mill spotless) (Temple de Mars [after September 1475], 1:76, v. 320; Complainte sur la mort Madame d'Ostrisse [after

21. The Hague, Koninklijke Bibliotheek, ms. $128 \mathrm{C}_{5}$, fol. 239. The prologue also contains allusions to Molinet's metaphorical Other: "Et affin que je ne perde le fourment de ma labeur et que la farine qui en sera molute puist avoir fleur salutaire, j'ay intencion, se Dieu me donne la grace, de tourner et convertir soubz mes rudes meules le vicieux au virtueux, le corporel a l'espirituel, la mondainté en divinité et souverainement de le moraliser" (And so that I do not lose the wheat of my labor and that the meal which will be ground by it can yield wholesome flour, I intend, if God gives me grace, to turn and convert beneath my plain millstones the corrupt into the virtuous, the corporal into the spiritual, the worldly into the divine, and to moralize about it in so excellent a manner) (fols. $\left.3^{\mathrm{v}}-4\right)$.

22. See the final verses of the Chappellet des dames (after July 1478, vv. 21-24) and the Arbre de Bourgogne (after April 1486, vv. 47-48). Molinet's references to the lack of wind to turn the mill's arms often allude to his lack of financial support, as the opening lines of the Ressource du petit peuple (after May 1481, (11. 1-4) and the final lines of the Trosne d'honneur (after June 1467, vv. 40-43) confirm. 
March 1482], 1:180, v. 496). This signatory gesture omitting the capitalized letter $M$ essentially eliminates the author's individuality (Scheidegger, 209). Yet, in a poem dedicated to Margaret of Austria in 1493, the same year the Vérard edition of the Art de rhétorique appeared, the author adopted his proper name instead of his punning signature when he announced, "Molinet vous salue" (Molinet greets you) (Collaudation a Madame Marguerite, 1:265, v. 98). In a circa 1494 poem, the metaphor is reduced to a simile, which equates author and object-_Je suis un molinet sans vent" (I am a little mill without wind) - but immediately thereafter, the image disappears and the narrator directly complains about his financial situation, in a conscious separation of name and image (Le revid a ung nommé Maitre Pol, 2:826, vv. 1-13). When Molinet again adopted the poetry-mill metaphor in two works written in 1496, he qualified the moulin with a human adjective, povre (poor). In one case, it modifies the object, but in the other the poet himself is thus portrayed: he describes "les vollans d'ung povre molinet" (the flywheels of a poor little mill) in the Voyage de Naples (1:277, 1. 7), whereas in Gaiges retrenchiés the final verses allude to the poet, not to the object, by referring to "le retour du povre Molinet / Qui n'a deja plus d'encre en son cornet" (2:771, vv. 79-80) (The return of the poor little mill/Molinet who no longer has any ink in its horn) ${ }^{23}$ Coexisting with textual allusions to the poetic windmill, the signatures of two poems dating from around 1497 depict only a human figure, the second one all the more clearly since the author's name appears without the definite article: "Le Molinet qui ne void que d'ung oeul" (The little mill/Molinet who sees with only one eye) ("A Madame Marguerite," 1:342, v. 42) and "Molinet . . . vous escripra" (Molinet will write to you) (Ballade, 1:346, v. 43). And in later examples: "Molinet prie a Dieu" (Molinet prays to God) (Nativité Madame Lienor [ca. 1498], 1:351, v. 113) and "Molinet . . . se prend au rimer" (Molinet begins to rhyme) (Lettre a monseigneur l'archiduc quand il alla en Espaine [after November 1501], 1:372, v. 28).

What accounts for this post-1493 shift from the plurality of meanings associated with the author's name to the one-dimensionality of the proper name? What explains Molinet's interest at the very end of his career in overseeing the publication of some of his own works, one of which, the Naissance de Charles d'Autriche, portrays a mark prominently bearing his name? Molinet's efforts to ensure that his identification with his texts be maintained were seemingly related to the aggressive actions of Parisian publishers who had deformed his works in the various ways

23. Since Molinet's economic difficulties constituted the subject of this piece, he exploited the metaphor of the moulinet here more than in any other poem. The poet alternates between references to the poetry mill's difficulties in functioning and the writer's own financial problems (see Chapter 5 below for an analysis). 
noted above. At first, like a painter's name that constituted an integral feature of the tableau, Molinet's signature was incorporated into the fabric of his texts because of that signature's capacity to function as a depersonalized object; these were texts that placed greater emphasis on the name and fame of his protectors. Eventually, though, Molinet's signature came to resemble that of the artist of his time which, painted on the canvas without being integrated with the subject matter, stood out from the work itself and, in certain cases, from the images of patrons portrayed therein. ${ }^{24}$ In such a form, the signature of the poet-or paintermore boldly proclaimed one's authorship.

André de la Vigne's association with the world of print accompanied important modifications in his signature. Whereas Molinet authorized his texts more and more often with his proper name instead of his punning signature toward the end of his career, La Vigne had replaced his metaphorical signature with a more straightforward form of his name by mid-career. This modification coincided with changes in how he expressed his relationship with his patrons.

Two series of acrostics naming the French king generate the speeches of Magesté Royalle, the monarch's alter ego, in La Vigne's Ressource de la Chrestienté of 1494. Like Vérard's (or Croy's) adoption of CHARLES DE VALoIs at the end of his edition of Molinet's Art de rhétorique, the appearance of this same acrostic in the Ressource derived from the author's hope of obtaining Charles VIII's patronage by this and other forms of flattery. Unlike Vérard's publication, however, which bore no sign of Molinet's authorship, La Vigne inscribed his name into the last verses of the Ressource, thereby seeking for himself the same kind of immortality provided by the incorporation of his prospective patron's name into the work.

As a verbal mirroring of the presentation scene depicted on the frontispiece of B.N. ms. f.fr. 1687 of the Ressource (see Figure 3.1), the first acrostic, CHARLES DE VALOIS, generates the text, sometimes in reverse order and sometimes along two vertical axes, at the beginning and at the hemistich of the verse. The patron's name thereby determined the pseudo-ballad's structure, giving rise to the list of virtues associated with him and essentially leading the reader "du nom porte-lettres au renom porte-vertus" (from the letter-bearing name to virtue-bearing fame) (Figure 4.1) ${ }^{25}$ In Magesté Royalle's second speech, an acrostic spells out

24. For details on parallel developments of artists' signatures, see Revue de l'Art 26 (1974): 24-26, 29-43, 46-54.

25. This expression is adopted from Rigolot, Poétique, 31. See Ressource, 124-25, for a transcription of these verses; all citations are taken from this edition, unless otherwise noted. 
an entire idea (Ressource, 139-41): CHARLES HUITIESME ET DERNIER DE CE NOM PAR LA GRACE DE DIEU ROY DE FRANCE A QUI DIEU DOINT BONNE VIE ET LONGUE ET PARADIS A LA FIN (Charles VIII and last of this name, king of France by the grace of God, may He grant him a good, long life and Paradise in the end). Wishing to pay homage to the king, the author not only generated horizontally an entire speech from the monarch's name but, as a kind of intercessor, he himself voiced a prayer on Charles VIII's behalf on the vertical plane. In both manuscript versions of the Ressource de la Chrestienté (B.N. mss. f.fr. 1687 and 1699) an artist highlighted these acrostics referring to the French monarch by the use of different colors and spaces between the first and second letters, thereby stimulating the reader's eye to take account of the French king's name in its repeated and reversed vertical forms, even before reconstructing the horizontal text. Since Charles VIII was both the subject and the dedicatee of the manuscript version-Magesté Royalle, his literary counterpart, plays a decisive role in the debate that takes place, and manuscript 1687 was offered to the king-and since his presence dominates the work in both its literary and its ornamental conception, it is obvious that the goal of these versions was above all to praise and to please Charles VIII. ${ }^{26}$

In contrast, the author's association with the text, marked by his signature, takes on a more sober character. It is not until the end of the work that he identifies himself. As in Molinet's earlier compositions, La Vigne accomplishes this indirectly by means of a pun on his name and his poetic art, when he makes reference to the "fruyt De la vigne" (fruit of the vine) (my emphasis):

Et pour conclure, je vous pry, treschier sire Que le traicté vous plaise avoir en grace, Quoy que n'y soit la scïence Porphire, Ne la prudence de Virgille ou Bocace. Se mon engin eust plus grant efficace, J'eusse trop mieulx labouré et enté La Ressource de la Chrestienté, Qui a vous, sire, de presenter n'est digne, Ne plus ne mains que le fruyt De la vigne.

(vv. 1461-69)

And in conclusion, I pray, my beloved lord, that it please you to hold this treatise in favor, even though Porphyry's wisdom cannot be found in it, nor the prudence of Virgil or Boccaccio. If my abilities

26. Some of these ideas appear in different form in my "Text." 


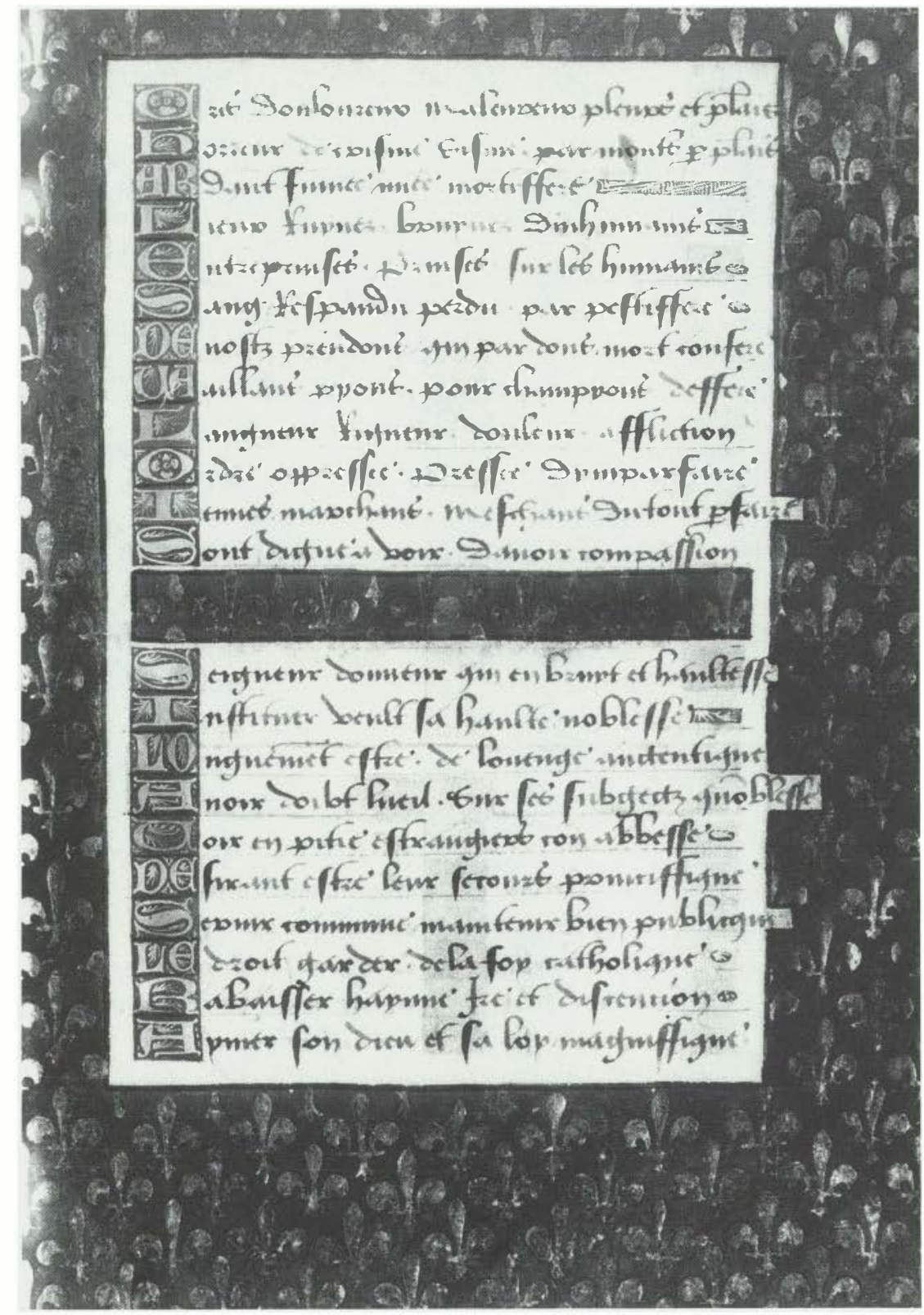

Fig. 4.1a. First 22 lines of Charles VIII acrostics, from La ressource de la Chrestienté, B.N., ms. f.fr. 1687 , fol. $24^{\mathrm{r}}$. C clichés Bibliothèque Nationale Paris. 


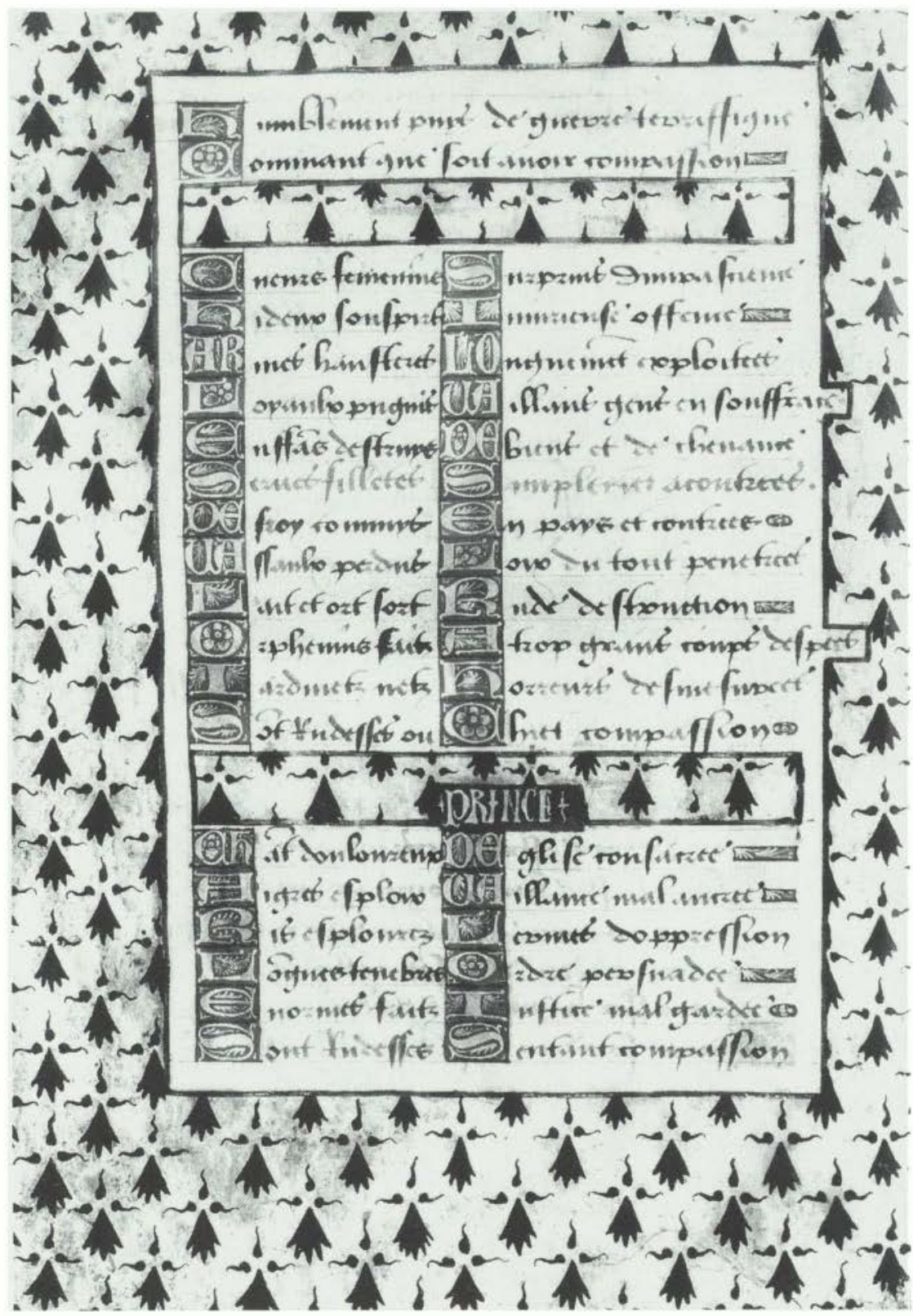

Fig. 4.1b. Last 20 lines of Charles VIII acrostics, fol. $24^{v}$. 
were more effective, I would have labored on and grafted much more the Ressource de la Chrestienté, which is not worthy of being presented to you, sire, any more or less than the fruit of the vine/La Vigne.

Exploiting the traditional parallels made between poetic production and the fruits of a gardener's labors, La Vigne's verses, his "fruit of the vine," develop after much labor and grafting. These words, the last of the poem, serve as the author's signature. At the same time, however, the author's identity risks being lost, because "De la vigne" plays a critical semantic role in the text, its concrete meaning bringing the horticultural discussion to a conclusion. ${ }^{27}$ Moreover, because no artist illuminated La Vigne's name like his patron's, it does not stand out so much visually. Nevertheless, in both manuscript versions, "De la Vigne" is set off from the rest of the verse with a capital $D$, as in manuscript 1687 (see my "Text," 110, fig. 4.3), or with a slash, period, and capital letter, as in manuscript 1699 (Figure 4.2).

Thus, the arrangement of names in the manuscript versions of the Ressource de la Chrestienté reflects a greater focus on the person in whose honor the text was written than on the author of the text. This selfaggrandizement was, of course, what the patron was paying for. ${ }^{28}$ The decoration and placement of names in manuscript 1687 , then, complement the presentation miniature depicting the poet on bended knee before his future patron: in both instances, the writer is deferential to the patron; but he is not completely absent.

The 1495 Angoulême edition of the Ressource, the first known printed version of the text, emphasizes neither the acrostics that focus on the identity of Charles VIII nor La Vigne's signature. Because this version completely lacked decoration, the two series of acrostics in it were not emphasized. Rubrics or other instructions to reconstruct the monarch's name are absent; nothing stimulates the reader to identify Charles de Valois as the focus of the work (see folio cii). For reasons of time perhaps, or cost, or lack of sophistication, the printers did not accentuate the acrostics. It is also possible that they simply were unaware of their existence, in which case they may have obtained the text through oral transmission. The Angoulême edition is the only extant version of the Res-

27. La Vigne signed his Complaintes et epitaphes du roy de la Bazoche with an even less accessible metaphorical signature (my emphasis): "Cy j'estandré de la vigne ung vert jus" (Here I will squeeze from the vine a green juice). See Recueil de poésies, ed. Montaiglon and Rothschild, 13:412.

28. Manuscript 1699, made for Duke Charles d'Angoulême, would have served as a model for its owner, although the glorification of his relative Charles VIII certainly reflected back on the duke as well. 


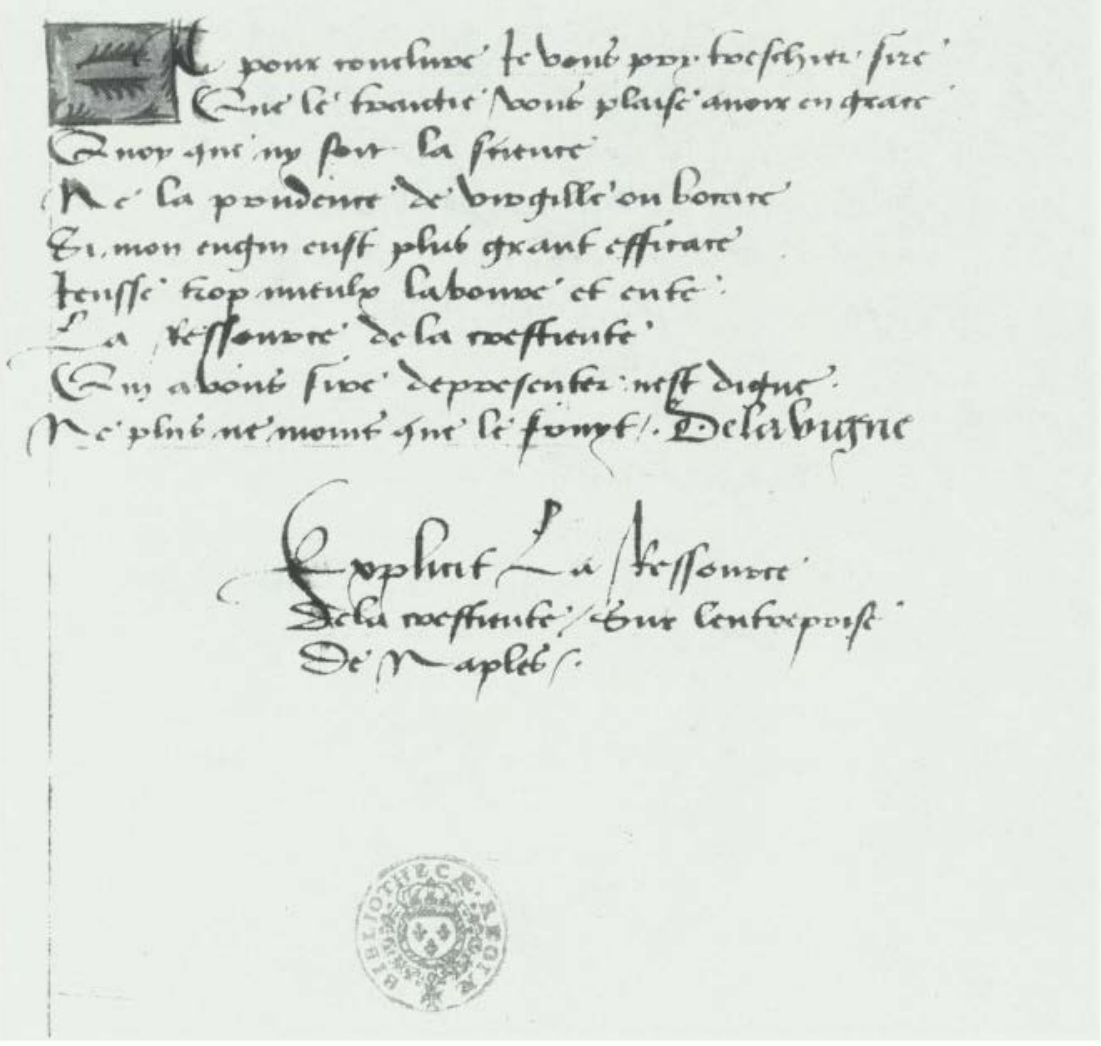

Fig. 4.2. Author's name at the end of final verse (emphasized), from La ressource de la Chrestienté, B.N., ms. f.fr. 1699, fol. $45^{\vee}$. (C) cliché Bibliothèque Nationale Paris.

source de la Chrestienté in which the acrostics remain unhighlighted. Moreover, the work's final words, which had functioned at once as a signature and as an integral part of the metaphorical conclusion in the manuscripts, are not emphasized at the end of the Angoulême edition (Figure 4.3). Just as readers would have been likely to overlook Charles VIII's presence in this version, because of a lack of ornamentation and an absence of highlighted acrostics, so too they probably would not have noticed the author's signature.

The editors of the Vergier d'honneur editions, however, do underscore the acrostics and La Vigne's signature in the Ressource de la Chrestienté, albeit in a different way than in the manuscripts. To call attention to the king's name, they have left a space between the acrostics on the vertical 
Et pour conclute ie Sous paie cjer fire Due le traicte Bous plaife auoir en grace Quop que ne foit fa fcience pospgite Rela paubence de Birgile ou bocace Se mois engin eult plus grant efficace Jeulfe frop mieulp laboure ente La refourfe de la creftiente Qui a bous fire de prefenter neft oigne Re plus ne moins que le fruict oeks bigne

\section{Ep finece petit fraicte appelie la tefourfe be creftiente fur Rempaife de napter.}

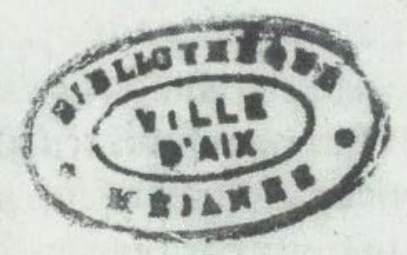

Fig. 4.3. Author's name at the end of final verse (unemphasized), from $\mathrm{La}$ ressource de la Chrestienté, 1st ed., Bibliothèque Méjanes, D.14-15, fol. 35v.

plane and the horizontal verse (Figure 4.4) ${ }^{29}$ The author, too, is given a place of greater importance in these versions of the Ressource. As I pointed out above, these editions call attention to André de la Vigne from the outset with the placement of his name on the title page, a development that the change from patron-oriented to author-oriented illustrations decorating these versions reinforces. Corroborating this new paratextual emphasis on authorship, the final verses of the Ressource draw our attention to the poet's identity by naming him directly instead of through the pun on his name that had appeared earlier in the manu-

29. In the fifth and sixth Vergier d'honneur editions, however, the acrostic generating the second speech of Magesté Royalle is not visually emphasized. Was this another example of a publisher's carelessness? 
andeuanf. En teboutant et dof prifant [ [es par

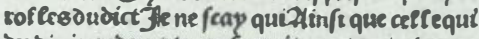
as diuin redempteut ef petoit et attenboitcon: feil confortapoeet fecout soccueutçay porfi bere commanca a parlet.etoit cainfi

\section{क्aicferopatse}

ICBat ite mife cn pitopable office

* omme coutonne de diuinbenefice

Eo dignees cieule ou trpo/êt lee / aincte

5) autte louenge fuy weno (on / actifice

5) ząy Grupt donneut fontretiêt en police

3 nnumetableentre tousfes bumains

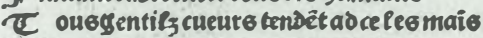

31 opcufemètet de bicn ede lopplaine

E nfontdoues tant alasire quaucospo

S) iebopsoncfut arftience mains

(T) aul eperpeter Enooystepasors maine

E ftre apresdicu /ut tousmifetisose

Ee poutcedonicmo o d tels fails contenople

Ze dene le chief nay cerielle ne temple

32 i icicup/e/bas/en' fen/ uaftre

72 eauftrec fofe qui de pitie ne fentefe

3 equicongnois befftuite nof the kerpile

E. $t$ molefter dame creftiente

३R aif on commanoe $y$ poutroirdequite

De fitardant ne mafe faictquitte

II on silosoonne y mettre refifance

e f poirde miculetet conf anguinite

20 Biefe au/li par/ingularite

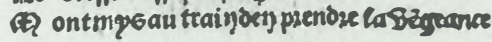

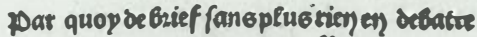
fa men) pray ure deoupteet of $b a t$ tre is oxrietertient quopquing parle ou quobiffe ३R uetparkerte (eemaftin日et combatte 2 force batmes pout on tout les abatre IIC cop faí ant dicu me/ $\mathrm{cta}$ propice - e reboutettel ctuct male fice \& fienuetoluy ma inguliete office ontpour bacquict et (afut de mon ame II escule al ext fano nulmalet fanosice (E) n ma plonne faitecefacm fice so ertientouna perficuto de mon royaulme

3Royne des anges empcrictedes cieule Siose oiuine, fip tref Ju 6 ftancicus
7) mage boulcepaffer of ectetnece

(2) pamant nect cutio folacieup

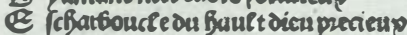

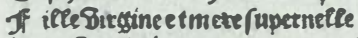
IR upffeau deiope dame pcepetuelfe 2 fin quemieule ma pet fonte f c gatde D2 emougliegourant cefte quetelle ic on/rifics moy satoz 3 mop de cautelle E tme cresenbofter aulucyatio

24 nger alefteosuttorne deifique I2 ui auez nomedef fence ferapjique

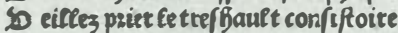
3) ufquesadcequedamout magnifique tonnermepuiffe fur cect) paciffique 3. opeauctentiquect entiete Bictoite e t Bousauffiocconf ore, repetioite so raiefaictoet fainctesen cômun auditoite to ulces patolfes deuaut dicu prefentes 3 nceffarvitent affinguede (a gloite 12 ousenlunine et def pee et Sufgeait c. ouemes ennemper openemal contes

250 ec 22. obleof tancope quide faience et date (2) fers aumondeplue Settueup nommes sDi fteet be Bricf Boze/pres et daro

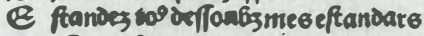
Et sous fetez miarle quonsques renzmes 2. eues souefuecommegenebien fames (iD) u ieso'tienepoutiantaio viffumes 22. uozet or f prio de plue bonneutacquette 5 entily tufteset Baillano gene; dames is eillegmonftet psefent fi Bous mapmes \& tme /upuestantpatmpt que pattetre.

Ee pourconclute seng touebatoyment pout Boit (aues en Bos corpebatcestert 28 oftermptifeou dieu nousconoupra 3a lieg Bous cat beritablement Di euadonnea celup fauluement B itoftque lamedef on cospspattita 24 uffilepapenous fauorifeta E ecommun pauple bieioyeupen feta $\mathcal{A}$ inficoncques fanef aitre autreopanch fi lis de ief us on nous detlaiteta i2 os cosperes cienle il glosifieta In fecula feculosumounen sactente

Fig. 4.4. Second acrostic pertaining to Charles VIII, from Le vergier d'honneur, 1st ed., B.N., Réserve $4^{\circ} \mathrm{Lb}^{28} 15 \alpha$, fol. $b v^{v}$. (C) cliché Bibliothèque Nationale Paris. 
scripts and the Angoulême edition. Consequently, there no longer exists any ambiguity about the author's name or his function in the Vergier $d^{\prime}$ honneur editions. While changing the original title of the Ressource to an announcement about the subsequent work in the anthology, his Entreprise de Naples, La Vigne identifies himself in a straightforward manner as the king's orator:

\section{J'eusse trop mieulx e(s)t sans nulle reprise \\ Mis en avant de Napples l'ent[r]eprise \\ Que vous presente en vers, coupletz et ligne, \\ Vostre treshumble orateur, De la vigne.}

I would have put forward in better fashion and without any reprimand, the Naples Enterprise, which is presented to you in verse, stanza, and line by your very humble orator, De la Vigne. ${ }^{30}$

Even though he ended up signing in the more distanced third-person voice, La Vigne's name, by participating in the first-person discourse of this last stanza, becomes more personalized in comparison with its metaphorical rendition in the manuscript and Angoulême versions. While this is impossible to confirm, there is very likely a relationship between La Vigne's change of signature and his involvement in the publication of the Vergier d'honneur collection.

Surely the evolution of signatures in the different versions of the Ressource de la Chrestienté, the author's increasing paratextual visibility in the Vergier d'honneur editions, and his historical control of them must be more than coincidental. Like the shift from the multiple meanings of the proper name to the one-dimensional form that characterized Molinet's signature in his later works, the change from La Vigne's punning signature to its direct expression reflects the author's redirection from a more sophisticated court audience, which enjoyed decoding name games, to a more literal-minded bourgeois public, which was sure to recognize the more straightforward signature. Occurring at the same time that La Vigne took control of the publication of the Ressource, the latter change can also be read as an affirmation of the author's desire to control from within and from without not only his creation, but also the dissemination of his work, name, and image.

Other examples of playful signatures and name games figure in the same Vergier d'honneur anthology, making it a virtual repository of ono-

30. [Paris: Pierre Le Dru, ca. 1502-3], fol. $12^{\mathrm{r}}$. The emphasized words represent the textual alterations made to the earlier versions. All citations from the Vergier d'honneur versions will be taken from this edition unless otherwise noted. 
mastic devices. In several compositions, La Vigne and his cohorts render homage to different French nobles by structuring poems around their names through the use of acrostics. ${ }^{31}$ In every case, a space between the first letter and the remainder of each verse highlights the vertical name created by the acrostic. One even finds poems in which La Vigne's admirers pay him tribute by using his name metaphorically and in acrostics. ${ }^{32}$ Unlike the acrostics constructed around the names of nobles in many poems in this collection, however, the acrostics of La Vigne's name in these works do not stand out. In one poem, an acrostic contains both La Vigne's name and that of Madame Catherine de Tieullière, in whose honor the author presumably penned the verses (fols. $\mathrm{L}$ iii-L iiiv). But only Catherine's identity is highlighted here (Figure 4.5). Why did the poet's name not figure prominently like that of his aristocratic dedicatee? Was La Vigne, who participated in the publication of the first two editions of the Vergier d'honneur, conscious of this differentiation? Perhaps the fact that this was a love poem had something to do with the greater discretion used by the poet in signing his name acrostically, especially since the voice of the poetic "I" plays such a critical role in these verses. The configuration of names nonetheless recalls the manuscript version of the Ressource, which accorded prominence to the patron's identity over that of the author.

La Vigne's acrostic signature is accentuated, however, in several other writings in the Vergier d'honneur collection. He signs his Voyage de Naples in the following manner (Figure 4.6):

Dedens Lÿon en trespuissant seig(n)eur

Et en triumphe de bruit chevaleureux,

Le per sans per, de vertus enseigneur,

A lors se tint comme victorieux,

$\mathrm{V}$ ray pocesseur de renom glorieux,

Incomparable en decoration,

31. See the ballades and rondeaux that are constructed around the following names: François de Vendôme (fol. o iv v), Charles (fol. viiv), Philippe de Savoye (fol. vivv), George $\mathrm{d}^{\prime}$ Amboise (fol. v v v), Charles de Bourbon (fols. A iv, A vi-A viv), Charles d'Angoulême $\left(\right.$ fol. $A v^{v}{ }^{v}$ ), le duc et la duchesse de Lorraine (fols. B ii and $F v^{v}$ ), etc. It is not possible to determine whether La Vigne wrote all these poems himself, although the rubric on fol. $v$ iiiv, "faictes et composees tant par les devant ditz acteurs [La Vigne and Octavien de SaintGelais] que plusieurs autres fatistes, orateurs et habilles compositeurs" (written and composed as much by the aforementioned authors as by several other poets, orators, and talented composers), suggests that these poems were composed by many different poets.

32. See fols. $B v^{v}, B$ vi, and $C i$. Since these verses praise the poet, it is very unlikely that he composed them on his own behalf. Nevertheless, they were presumably incorporated into the anthology by La Vigne himself, thereby offering another example of his growing sense of self-importance. 
Se neprefezonute oubite Dul ne sous o/ctabe pite ze cela ie Bousen auife

pmactines quelque deui/e I aiffarit after beulet foucy E) aisque fa matiete foil mife Entrainauant que foit befmire Te bire quelque chofe aufi

Dulne oti mot / bea que Tecy. socult on point matiere entamet (t) ovente qui eftesicy puis queckafcunenfait ainfi Eeuif ons bu be baye baimet

comblen que de bouls en amex Zu/f fouuantque te Bent Bente ceutnede| ho tette el fus met Jen Seuts pout mon Buet confunet Datfet pat wil on appatente

Amour ceril ce foucp prefente A plulieureprtis niweits Tormme mop qui mis monentente De me metere en la oure fente Dontiay fommains manfe noumetres

\section{5 affade}

(n) At turbinnece excertantedasue 21 quicie dopes fonneut etruetáce ze to 9 me giene on coupe aufi be lante

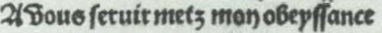
Cairoit bonneut nemply de grat piaifare eftoilte cleteplus que to/e Betmette De toue mon fene el foute tria prifance E)

Bonneut Baultain (bef fe toute Geaute Amour notabte corpe de matsifificne 3Ropne dee brlles platne oumifite Dioic eetfautte comble de lopaulte En tous bas faits bo oil on lepperience St) at6ze poly ymaigse de plaifance Sneques au monoe ne fut scul a peile

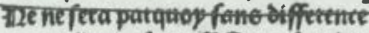
coufiourefane fi sous fetuit mapeile
G)aisquon quil foic fe te me trenue inditge Cte Foutce bame be bantfayne bateut deoue fe moinemon amour qui Bous guighe Moubfiez paecat Bousauez f a fleur De Bous fetuit fanece fer:be bon cueue 12aifon commande quad ce ie me trancile Eequipluseft be bire pat Bonncut SDousbien fecait touf routs ie mapateille

Ee toutes dames de femmes ne de filles Iefquettes Beiffe oncqnes iour be ma Bie Xinour nauoit tane fu|fent ette Babiltes Sc aincu moncuett fors Bouøie Bous a fipe Je Bouspromects que Bous feres fetuic fDatlate oc mop qui que patect en Bucte he datutre dane famaicionoutapennie En ceftup monde souseftes nompatedle

pince

Et fe Bne foye Boftre antout cflatdite Creaue en droitmoy cropes fe ne fortutitle Sue bautfement ditap fane biftenyen Dncques fut tette nen fut Beu tapateifte

\section{Baflabe}

(1) Dn Bienmamout et ma feufte efpance 21 quite dove bounetxe ef reuetance

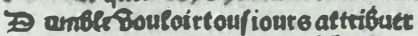
24 Sowe louer be coute ma puifl ance

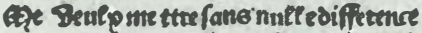
If omme celuy qaísous Seure Baultlouet I toufioute mais anspoinep surict ce iendra foy cueve libetalet entiet 5 onneftement enbroit Bous fane fattace \& $t$ quoy quif oofue pour bou 6 erte entoutet 32 imnclay ef tieat pout toutbenl paffet De quift awott que Bof fte Bonsic'stace

Is oulce mofitrefe tentplyebe beaulfe e trebontt patfaicte Bumitite of imt tn ions feulle fon fiege tribural 3 eune iopenfe francfire copaulte

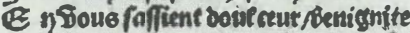
50 oit on fut Bouebunctefte ftiumpial fumbte de ofumbles eftre amont asol

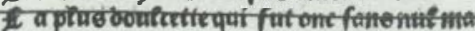
Jef uis tran/pquant is Bop- Bo fte face

\section{Liil}

Fig. 4.5a. First 21 lines of Madame Catherine de Tieullière's acrostic (emphasized), from Le vergier d'honneur, 1st ed., B.N., Réserve, $4^{\circ} \mathrm{Lb}^{28} 15 \alpha$, fol. L iii. (C) clichés Bibliothèque Nationale Paris. 
e fouque fore apicbela cberal \is ienienequiers pour mon plaifir total E yceftup monde que Boftre bonne grace

Defirmafaule/ee foucp me tournente En taus cnosois qua bous ie me pief ente fopal encueur et parfait encoutaige dutte que sous mon plaifit ne concente socu quen Bous /eulfe ap mife monentente Fincontinantpar Softrebeau langaige Tonte misgnonne of cucur et de $\cos$ (aige \#206ledec/k au gracieup Bifaige Efprit fubtil qui tous mes maulpefface bertueup cfief ferme conftant et laige Jie nepouteba/feen poseneen pa|f sige Fors. feullancnt que dauoir Boftre grece

psinceffe bame pis obete cuat ymaige Xl quite senep faice fop, et bormaige Entous endrois fane aulcune fallace pour recenoir Boftre amouteup oirmaire 21ffin baftet iouer au 6operamagte Je ne cananoe que softre bonne grace

\section{3atlabe}

4 Emó pouoir le mieule detoulce nate 2toire boir con tiefe parfonde

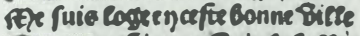
Eenay miftir que Soic labette et Gronbe ICat ceft facbofequi trop plus fout te donoe : Hup ef prie of mon pence mosite Con/ionts de cout/ou rond comme ine Gille Sormme ie fuis tufe/fin et abilte En sous fetuant tous les ioure or 68 cnent 3Retenes bons a poure cet forbille 3ufque a la mort/cat p mon/feut faince gitce \$2. Sou cairta Sof tre Gumble feruiteut

De $80 u$ soufiouts ay fetme foutenance Es nupt et iour pat Brape nemembzance Cout mon plaiftr eft de Boue conf ofer Jap telle iope en mon cueut quant is pence En Bous madame que fur ma conf cience

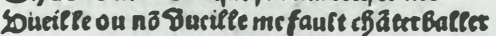
2026 ic prensiour ocuere Sousmenallet Re plus pracfain pout tirc de Gon cueur Jequi fuigoonc a Bous/ anepluspatlec Betenes movBofte bumbeferuitent

2 d deuba cief et a Sousen apzes poutiope auoir et pa/fetempe cepses
Eecueut pat faice bumbernaneme con $f y$ 3Raifon le Bcule/sarde Bous apou pies Soient mon plaifit tant oe loing que de pres 玉onesous reclante ma maifteffe iolpe Doftre doulceut mon pencer amolye Buanta bous (eulce bumblent fumilie faiffant tout deul et loute faulce entur biuteme faictes bosedemefencolye Batla dementen fair ant cbiere lye Me laifes pae Bofte Gumble frruiteut

Eepoutant donc be Sous /etuitenuic Saroviopeup be plaifance aflouaie SD que ie fope matreflopalte feuc Eeque ferapiay mis ma fantafie Sumble de cueur fans nucte bitlenpe Dncquesnacquiftes plusleal / etriteut

\section{5aflabe} S) anbuedonneur/esiap tepofitoite aup youle soyât softre te pouce frut terof are af ute ox sous biens confiftoite bumble boulcter digne or grant memoix Efoilte clere lup fant en tout place Ropne des betres qui toutes autres pale 3 Janais ne fuc au monde la patrifte De ne fera quopqaon ope ou quon face Enceftuplmonoc sous eftes nompartilte

3ap icu des filtes et fenmes Biats miltict Du grant Geaulte et grantbien repo/ oil Gonnefres/entes/preftes ababillet A Ingcfalcunqui opr fees ouloil Donobfantce/qui Softre Gien Bouctote nomonet ou bite bzieffe feroit metueifte El pourcerlatin Porechafan fidroic but toutreautces fite lanomparcilte

Ifer Sis Soyant et congnoifantfoutbien Zcompare a la nodempnetue Erofne afurepostantbsupterticn Saultaine f pit lequel' pat Bonmoyen Entous eftae soulezqueton Boueftrue xup feaude iope force eft que ie ma/ctue Incontinant a Bous Bueilte ou non Butte Depencant for 6 que Boftreamour deferue

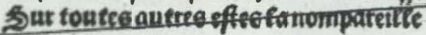

Drince

3. pryedien que toufiours il confretue En Gaultain brupt telte to fe Betmeilfs

Fig. 4.5b. Last 3 lines of Madame Catherine de Tieullière's acrostic (emphasized), and De La Vigne's acrostic (unemphasized), fol. L iii . 
rop opt la meffe ambit cutink poif nawee apo cifner allacoucfera quitets.

Lel iot. pip.iourboctobre denouna anơ qets Et Celendemain $\phi$ fut mracoi pp.oubie moys if optmeffe et difna a quiete. puis apses oifs net fut coucfet a שutin.

ICoditiout bontconte Bine 2 Busgiefme. ou mop sooctobsebe cutin print congrie etlendemain qui fut Bine coeupie me fut a tiuole puis a Sozeloge Crefbien recen doulcoment betferche sesgene tuaintez de tre bonne facon Cant de gifict de cbaic quede poiffon De Sine siandes de pain blance pain Gsun fe Senoredi if actint 2Bsianflon:

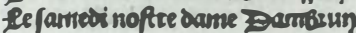

Pelendemain a Sauine dir na' Etoefauineil fut a forpcoudiet 24 faint epirefe lundidef tuna puis fit fes gene 2l la meutemateset Et lematdipout pais def per det pafanepar cautr a gremoble (en sint Sa pout Bng maf qui au cueut lap futuine Le metcrebi ne partic de fa cfanbre Ee poutemieuty feioutnet lup conuint

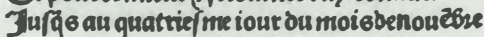

Iedic iour bont cotalcment guety De gemoble partil aleigre et (aii) Eef utbifneriopeup etnon matty X faint tambett et coucbet a morain Jeubi matin (ans auoí le cueur Bain): Il f ut difneten Bngbeau petit fica Quondit Sillon lequel ftaumitieu Duy lieu cbampaiftre eftorc de sout6ien! Apres difnet la cofte faint andieu pourgifte print ou tecen fut tref bien

Re senoredi toucte monde matcba Eefuctc rop a cBatonay di/net pui6en Bng lieu de plail ance coucba Etcela fiten triump fe ozoonnet pout en lpon trefBien lacompaignet Seigneute elaultre grtos o gtä 6 p/onnaiges Sand oblement on fildeuant menet Cousles babus cberiots et bayaigre. fle fanebi fepticfine de nouenbse fe top des roye preup entre Ing mittion

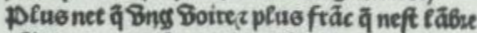
fit gfapentent (on entree a \&pon)

Entout Bonneut/en paipen Snion En geoire en los en post en pre fetence Et en fees atmes postant par evcelence Te quon ne bit puis le tentpe dabraban 2tinfique top/fles fleusoclis de france Et lee trefoignes/ctois de ifferu/alem.

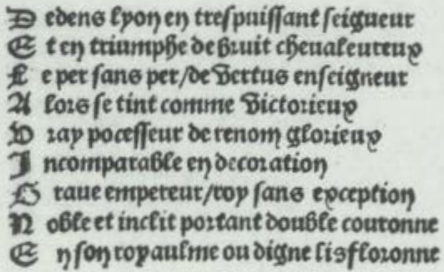

Fig. 4.6. La Vigne's acrostic (emphasized), from Le vergier d'honneur, 1st ed. B.N., Réserve $4^{\circ} \mathrm{Lb}^{28} 15 \alpha$, fol. o $v^{v}$. (C) cliché Bibliothèque Nationale Paris. 
G rave empereur, roy sans exception, Noble et inclit, portant double couronne, En son royaulme ou digne lis floronne.

$\left(\right.$ fol. o v $v^{v}$

Into Lyons as a very powerful lord and in the triumph of chivalric reputation, the peer without peer, teacher of virtues, held himself victorious, true possessor of glorious renown, incomparable in decoration, stately emperor, king without exception, noble and famous, bearing a double crown, into his kingdom where the proud lily blooms.

In contrast to the unaccentuated acrostic signature in the previously discussed poem, this first edition of the Vergier d'honneur highlighted DE LA VIGNE in the same manner as the acrostics of noble names. This signature, however, does not work in quite the same way as its aristocratic counterpart. For the horizontal text generated by the author's name does not reflect back on the person associated with the vertically generated name by listing his virtues: this would have appeared too self-serving. Instead, DE LA VIGNE generated praise of the poet's patron, of his nom and renom, with the chronicler speaking in a third-person voice. Glorification flows from the author's name as it does from his pen. This association between the author's name and the generated text praising the "idealized Other" serves to convey the writer's subservient relationship to his patron, for the words emanating from La Vigne's name glorify Charles VIII. At the same time, the vertical advertisement of the author's presence reminds the reader that the king was dependent on his court secretary for the re-creation of his image in words. This adoption of the acrostic form for authorial signatures, with its vertical and horizontal modes, thus translated the developing relationship of exchange between patron and poet in late medieval French propagandistic literature better than the punning signature. Whereas punning signatures were generated from the verse, a product of carefully crafted words, the vertical arrangement of the poet's name at the head of each line reinforces the idea that the author engenders the text. Since his name does not figure in the poem's horizontal meaning, the acrostic signature remains more separate from the text than a punning signature, pointing more obviously outward to its personal referent. In this way, the acrostic plays a more crucial structural role, because each of its letters simultaneously serves horizontal and vertical functions.

La Vigne uses the same emphasized acrostic device to punctuate other compositions appearing in the Vergier d'honneur collection, including Les louenges du roy faictes par l'Eglise, Noblesse, Prouesse et Honneur (fol. $\left.\mathrm{p} \mathrm{v}^{\mathrm{v}}\right)$, 
Le temps de l'annee moralizé (fol. $\mathrm{r} \mathrm{i}^{\mathrm{v}}$ ), and Chascun (fol. $\mathrm{r}$ iii). In each case, extra spacing between the first and second letters of every verse highlights La Vigne's name. Moreover, the speaker does not assume the third-person stance of his earlier punning and acrostic signatures; he adopts instead the more personal and forceful first-person voice. In the Louenges, for example, the poet's vertically placed name, generating a horizontal diatribe against Italians in support of French military policy during the Italian Wars, acts as a "spokesman" for the king:

D oncques Rommains, gros Lombars, Millannoys,

Et vous Tuscans, qui[l] avez mil harnoys,

Levez et pris pour (nu)yre en tout desroy

A ux bons Francoys, qui le goust de la noys

Vous a baillé, tant que plus dela ne oys

J oindre ou hongner l'Itallye en charroy,

Gardez, craignez, servez, aymez le roy

Noble et entier soubz lequel apprendre a

Et soyez seur que bien vous en prandra. (fol. $p v^{v}$ )

Therefore, Romans, stout Lombards, Milanese, and you Tuscans, who have raised and taken a thousand pieces of armor to destroy good Frenchmen, who gave you the taste of snow, so much so that beyond that you do not hear Italy threatening or grumbling in the streets: Watch out, fear, serve, love the noble and honest king under whom there is much to learn. And rest assured that he will take good from you.

La Vigne's acrostic signature likewise punctuates the work he wrote following his Parlement victory over Michel Le Noir, an account of Queen Anne of Brittany's entry into Paris in November 1504. The particular configuration of the author's name here offers evidence of yet another modification in La Vigne's use of the acrostic signature. It stands out all the more in this version because of its special, illuminated presentation (Figure 4.7): ${ }^{33}$

Dame d'onneur, Royne par excellence

Et Duchesse de grant magnifficence La plus digne qui fut onc en noblesse, A Vous je viens soubz toute Reverence Vous apporter l'euvre qu'en Vostre absence

33. This work remained in manuscript form (see Stein, 268-304, and Waddesdon Manor, Rothschild Collection, ms. Delaissé 22, fol. 64). 


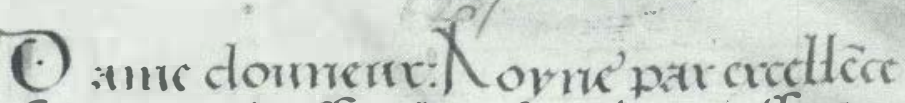

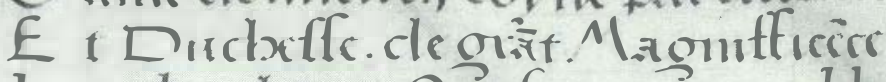 \\ $L$ a plusdrome: Orif fut one cumoblelle \\ A Vousfeliens Sombs toute Aenerife

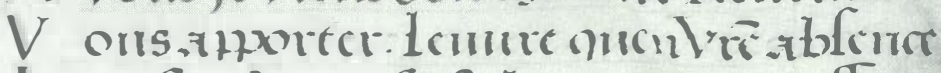 \\ 1. al-ficto andi: Sclon mia petitefte

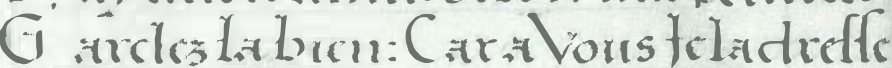

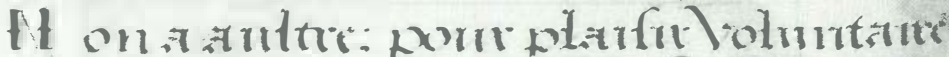 \\ E, thomblos: Vin brmble fecretame -}

Fig. 4.7. La Vigne's illuminated acrostic, from Le couronnement d'Anne de Bretagne, Waddesdon Manor, ms. Delaissé 22, fol. 64. The National Trust, Waddesdon Manor.

I'ay faicte ainsi selon ma petitesse.

G ardez la bien: car a Vous je l'adresse

$\mathrm{N}$ on a aultre, pour plaisir voluntaire

Et n'oubliez Vostre humble secretaire.

Lady of honor, queen par excellence and duchess of great magnificence, the most worthy noble ever, I come to you in all reverence to bring you the work I wrote in your absence, according to my humble state. Guard it carefully: for I address it to you, to no other, out of voluntary pleasure. And forget not your humble secretary.

This highlighting of the author's name may be related to La Vigne's involvement in the Vergier d'honneur publications, which had accentuated DE LA VIGNE in a corresponding, albeit less ornate, manner. The writer's self-identification here resembles that found at the end of his Voyage de Naples, which had likewise marked a noble entry, Charles VIII's return to Lyons from Italy in November 1495. The strategy employed in La Vigne's description of Anne of Brittany's Parisian arrival nine years later is 
slightly different, however. While praise for Anne literally emerges from La Vigne's name, just as it had for Charles VIII, the poet also places emphasis on himself in these verses. Reference to the composition he has written in her honor and his appeal to be remembered as her secretary form an important counterpoint to the epideictic discourse that formerly dominated the horizontal text of La Vigne's and others' acrostics. Although the final reference, "Vostre humble secretaire," is formulated in the third person, La Vigne's overall perspective is that of a first-person speaker, which emphasizes all the more his presence. Thus, some of the meaning associated with the vertical representation of the author's name, which had heretofore remained distanced from the generated text, has penetrated the horizontal plane of this acrostic, signaling the infiltration of the poet's persona into his own narrative, a subject I will examine at greater length in the next chapter.

In the ten years between La Vigne's 1494 Ressource de la Chrestienté, in support of King Charles VIII, and his 1504 dedication to Queen Anne of Brittany, the author had come to sign in a more direct way. La Vigne's replacement of his punning name with an acrostic signature to publicize textually his authorship, instead of just the virtues of his patroness, and his appropriation of the form that had served to designate his patrons in earlier compositions reflect his growing self-confidence and selfawareness as a writer. The five works of La Vigne that were published during his tenure as secretary to Queen Anne contain no textual signature whatsoever. In every case, though, a prominent announcement of La Vigne as the author of the work and as the French queen's secretary figures on the title page (L'atollite portas de Gennes [1507], Les ballades de Bruyt Commun [1509], Le libelle des cinq villes d'Ytallye contre Venise [1509], Epitaphes en rondeaux de la royne [1514]) or in the preceding rubric ( $\mathrm{La} \mathrm{Pa-}$ tenostre des Genevois [1507]). ${ }^{34}$ In these works, which do not constitute narratives but rather a series of ballades or rondeaux, the author's voice plays no integral role within the text itself. It is as if at the very time La Vigne was detaching his voice from the fiction of his literary text to emphasize his external role as author, the paratext was becoming a more reliable space in which he could identify himself. Although La Vigne did not go to the extent of Jean Lemaire, who increasingly expanded the prefatory space of his works with letters of dedication and selfglorification and with prologues, the use of witty verse announcements about La Vigne's literary accomplishments in the service of the French court on the title page of the Ballades de Bruyt Commun and Libelle des cinq

34. See my Shaping, 163-86, and Recueil de poésies, ed. Montaiglon and Rothschild, 12:105. 
villes $d^{\prime} Y$ tallye (see Figure 2.11a-b) attest to the successful outcome of his 1504 lawsuit, for his name had become a validated part of the publisher's enterprise (see my Shaping, 173, 179).

In signing his writings with an acrostic as he did at the end of his very first work, Pierre Gringore identified himself more literally than, though just as playfully as, Molinet and La Vigne had at the beginning of their careers. Gringore chose the acrostic form, perhaps, because his name did not lend itself to wordplay like his contemporaries' and because his audience, at least until 1518, encompassed a less sophisticated, noncourtly public. But the use of elaborate rubrics to alert the reader to the presence of Gringore's signature confirms that recognition of the author's name had become a defined goal of those involved in the printing of his works, including the poet himself. This continued action of ensuring name recognition, Gringore's acquisition of his first privilege in 1505 for the Folles entreprises and for many of his publications thereafter, and his strategy of overseeing the printing of the first editions of his works as a means of controlling later unauthorized editions may be related to an unusual incident that occurred in late 1500 in which the printer Michel Le Noir not only published Gringore's work without his authorization but appropriated his authorship of it through a manipulation of Gringore's acrostic signature.

It is in the last stanza of Gringore's Chasteau de labour of 1499 that the reader discovers the poet's name for the first time. The eight final verses of the work form a signature acrostic that will mark nearly all his subsequent writings:

\section{L'acteur}

Grace rendz au hault Createur

Regnant en triumphe haultaine,

Invocant le povre pecheur

Nourry en la gloire mondaine,

Gardien de nature humaine,

Omnipotent, plain de noblesse,

Resplendissant au hault demaine,

Estendant sur nous sa largesse. ${ }^{35}$

The Author: Grant favor to the Creator reigning on high in stately triumph, invoking the poor sinner, nourished in worldly glory, Guardian of human nature, omnipotent, full of nobility, radiant in His lofty domain, extending over us all His bounty.

35. Paris: Philippe Pigouchet for Simon Vostre, October 22, 1499, fol. f ix . 
By inscribing his signature into his text, Gringore ensured that subsequent editions, which might bear paratextual details determined by others besides himself, would retain his name. In fact, this acrostic stanza was the sole means of authorial identification in the many editions of the Chasteau de labour published up through the middle of the sixteenth century. The use of the rubric "L'acteur" (The Author), which makes the final stanza an epilogue by isolating it from the preceding text, alerts the reader to the author's voice, even if it does not specifically indicate the presence of his name in the vertical register.

Even more regularly than Molinet and La Vigne, Gringore made his name an integral part of the texts he created. Unlike both of the CHARLES DE VALOIS acrostics that appeared in Vérard's printed version of Molinet's Art de rhétorique and La Vigne's Ressource de la Chrestienté, the horizontal text of Gringore's Chasteau de labour does not extol the virtues of the name that generates it. As in the case of La Vigne's acrostic signature at the end of his Voyage de Naples, written just a few years earlier (1495), it would not have been appropriate for the author to create a selfcongratulatory text; such could be done, however, to glorify another. Yet, the words emanating from GRINGORE in the final stanza of the Chasteau de labour volumes do not serve an exclusively epideictic function. While the poet's voice offers extensive praise of God through his name, it also plays an exhortative role. For just as the acrostic signature mediates between the extratextual and textual worlds of the Chasteau de labour, just as it points simultaneously outward to the person behind the name and inward to the horizontal message, so too the author serves as an intermediary between the extratextual reader and the textual subject, in this case, God, urging the former to acknowledge the celestial goodness of the latter. In this way, the visual encoding of the author's name reinforces his poetic and rhetorical role as his words promote the Word of God. This same intercessory function characterizes the acrostics La Vigne placed at the end of Le temps de l'annee moralizé and Chascun, which appeared in print several years after Gringore's Chasteau (see p. 180 above).

The numerous editions of the Chasteau de labour, published between 1499 and 1529, indicate the work's great success in early sixteenthcentury Paris. More surprising, perhaps, was its popularity in England, attested to by the sixextant editions of the translated work that appeared in London between 1499 and $1510 .{ }^{36}$ In these English versions, however, the French author's name was absent from the final verses. While one might expect Gringore's acrostic signature to disappear through translation, there is no sign of his authorship anywhere in the English edi-

36. For a bibliographical listing, see Appendix 5 below. 
tions. Does this omission relate to the fact that the poet's name was absent from the title page and colophon of the French editions that doubtless served as the basis of the translation? Or does this constitute yet another example of a publisher's liberal "borrowing" of an author's work? Did a translator have any kind of obligation to the author of the text translated? Whatever the answer, another voice does claim proprietorship of the Castell of Labour. For the final acrostic in the Chasteau de labour has been replaced by an "Actoris excusatio" (my emphasis), presumably penned by the anonymous translator of the English version (see Pynson ed., ca. 1505, fols. $55^{\mathrm{r}}-55^{\mathrm{v}}$ ). While the English printers Richarde Pynson and Wynkyn de Worde took care to advertise their role in the publication of the Castell of Labour by placing their names in the colophon of their respective editions, they mentioned neither Gringore's nor the translator's name. ${ }^{37}$ It is quite possible that Gringore was unaware of the English publications of his work. And yet it was supposedly his own compatriot, the publisher Antoine Vérard, who had initiated the translation venture and attempted to sell the books he had had translated and published in London. ${ }^{38}$ Gringore would not have approved of Vérard's undertaking, which gave the author no credit whatsoever, but brought financial gain to the publisher. Even if he had been aware of Vérard's actions, though, the writer did not possess the necessary legal clout to rectify the situation..$^{39}$ Such adaptation of an author's works clearly benefited printers or publishers, but not writers. Although this manipulation of acrostic signatures could have-and may well haveoccurred under manuscript reproduction, the stakes were clearly higher with print's more technologically advanced system.

The English version of yet another composition by Gringore that was published for the London book market, his Complainte de Trop Tard Marié of 1505 , also eliminated the author's signature. ${ }^{40}$ This time, however, the

37. The title page of Pynson's 1505 edition announces only the title, stating "Here begynneth the castell of laboure," while the phrase "Emprynted be me Richarde Pynson" follows the "Actoris excusatio." Wynkyn de Worde's 1506 Castell of Labour title page follows Pynson's strategy, but more information about his edition is provided in the added colophon: "Thus endeth the Castell of Labour wherin is rychesse, vertue, and honour. Enprynted at London in Fletestrete in the sygne of the sonne by Wynkyn de Worde. Anno domini. M.CCCCC.vi."

38. Pollard, ed., The Castell of Labour, xvii, suggests that Alexander Barclay translated the work for Vérard in Paris around 1503-4. Only a fragment of this edition still exists. The "Actoris excusatio," which appears in the other complete English editions, presumably punctuated the last folios of Vérard's English version as well.

39. The jurisdiction of a French privilege, which was not even obtained for any of the Chasteau de labour publications, did not extend to foreign markets (see Armstrong, 1-20, 44).

40. Complaintede Trop Tard Marié (Paris: for Pierre Gringore, October 1,1505$)$, fol. $7^{v}$. For a bibliographical listing of the versions of this work, see Appendix 5 below. 
translator, Roberte Copland, boldly substituted his own acrostic signature for the French poet's. This represented a more blatant appropriation of the work, because the Complainte editions, from which the English translation must have derived, had clearly advertised Gringore's name in the colophon, where it reads: "Fait et composé par Pierre Gringore" (Written and composed by Pierre Gringore). The fact that Copland adopted a signature acrostic all but confirms that he was aware of, and probably inspired by, Gringore's. Like the translator of the Chasteau de labour, Copland is referred to in a rubric as the "auctour" of the Complaynte of Them That Ben To Late Maryed (my emphasis):

The auctour

Rychenes in youth, with good gouernaunce, Often helpeth age whan youth is gone his gate; Both yonge and olde must have theyr sustenaunce Euer in this worlde, soo fekyll and rethrogate: Ryght as an ampte, the whiche all gate, Trusseth and caryeth for his lyues fode, Eny thynge that whiche hym semeth to be good.

Crysten folke ought for to haue Open hertes vnto God almyght, Puttynge in theyr mynde thyr soule to saue, Lernynge to come vnto the eternall lyght, And kepe well theyr maryage and trouth plyght; Nothynge alwaye of theyr last ende, Durynge theyr lyues how they the tyme spende. ${ }^{41}$

Thus the translator prominently announced his re-creation of the Complainte, as did the printer, but the original author's name is absent. Although certain authors, such as Molinet with his modernization and moralization of the Roman de la rose, publicly acknowledged that they were translators-this was especially the case with famous texts-these English translations did not credit the original author of the Chasteau de labour and Complainte de Trop Tard Marié. In point of fact, the translators of these works were advertised as authors in their own right. Acknowledgment in the English versions of the authorship of Gringore, who was

41. Collier, ed., 1:18. The printer's name and address follow (my emphasis): "Here endeth the complaynt of to late maryed, / For spendynge of tyme or they a borde. / The fayd holy sacramente have to long taryed, / Humayne nature tassemble, and it to accorde. / Enprynted in Fletestrete by Wynkyn de Worde, / Dwellynge in the famous cyte of London, / His hous in the same at the sygne of the Sonne" (19). 


\section{Changing Authorial Signatures}

probably little known abroad, presumably would not have promoted book sales as much as the name of a local writer would have.

The disappearance of Gringore's acrostic signature in the translated versions of his works was perhaps understandable, even though the elimination of his identity was difficult to excuse. Its absence in French editions, however, can be attributed to sheer arrogance and greed, which doubtless motivated Le Noir in his publication of the Chasteau d'amours. $^{42}$

As in nearly all his works, Gringore's name, though unannounced on the title page of his second publication, generated the last stanza of his text. Moreover, a rubric directed the reader of Pigouchet's and Vostre's edition of the Chasteau d'amours to reconstruct GRINGORE vertically, reflecting perhaps a concern about its possibly not being recognized in acrostic form:

Le surnom de l'acteur qui a fait et composé ce livre par les premieres lettres de ce couplet:

Gens de bien qui lisez ce livre, Rememorez en voz couraiges Jeunesse qui maint assault livre: Nature conduit ses ouvraiges. Gardez tousjours le dit des saiges, Obtemperez a leur requeste, Recordez trestous ces passaiges En folle amour peu on acqueste. ${ }^{43}$

The last name of the author who made and composed this book [is to be known] by the first letters of this stanza: Good people who read this book, remember in your hearts youth, which wages many an assault; Nature leads its works. Always keep in mind the sayings of wise men, obey their request, record all these passages. In foolish love, one acquires little.

Thus, the author's name in its vertical register would have stood out on the last folio of the Chasteau d'amours to the eye of the potential buyer. As in the Chasteau de labour, the words generated by Gringore's name do not reflect back on the person behind the name but reach out in an intercessory way to the public, directly exhorting readers to ethical behavior.

42. Some of the following ideas have appeared in different form in my "Confrontation."

43. Paris: Philippe Pigouchet for Simon Vostre, n.d. [ca. 1500], fol. $44^{v}$. 


\section{Poets, Patrons, and Printers}

Once again the author-acteur plays the intermediary role of a moralist, one associated with the audience and somewhat above or outside it as well, just like the relationship between his name and the text it engenders. This change in the horizontal text from an epideictic, patronoriented discourse (characteristic of earlier acrostic stanzas like those in La Vigne's Ressource and Voyage de Naples) to a public-directed, exhortative discourse recalls some of La Vigne's final acrostic stanzas examined above. It also characterizes the narrative function of the acteur in Gringore's texts (see Chapter 5 below).

But the writer's name was not the only one identified at the end of the Chasteau d'amours. In the stanzas preceding his signed verses, the names of the printer and publisher were also cast into acrostic form and announced through a system of similar rubrics. Like the Gringore acrostics, these verses incite the reader to exemplary conduct (Figure 4.8): "Le nom de l'imprimeur qui a imprimé ce livre congnoistrez par les premieres lettres de ce couplet . . . Le nom du marchant qui a fait faire ce livre . . . Le surnom dudit marchant" (You will discover the name of the printer who printed this book in the first letters of this stanza . . The name of the merchant who had this book made . . . The last name of said merchant). The presence of acrostics identifying the printer and publisher as well as the author is rather unusual and suggests the same fear of misappropriation that the author may have felt. ${ }^{44}$ In a sense, they replace the patron acrostics found in many earlier manuscripts and incunabula, and they signal the increasingly dominant role in book reproduction played by printer and publisher, whogradually came to provide an alternative to patronage. Gringore was in fact more dependent on publishers than on patrons at this particular time. And yet, since he presumably governed this textual space, it is apparent that in composing this series of acrostic verses, Gringore sought to control publicity from within the text by absorbing into it the colophon, normally a paratextual feature regulated by the printer or publisher. That he wrote his own and the other acrostics suggests that Gringore actually authorized the publication of the Chasteau d'amours under the auspices of Pigouchet and Vostre.

Such was not the case, however, with Le Noir's December 1500 edition of the Chasteau d'amours, in which dramatic alterations were made to the acrostics. While Le Noir had the verses that spelled out the names of Pigouchet and Vostre in earlier editions reprinted, perhaps because they

44. The printer Pigouchet was earlier associated with acrostic use, for he is named with his patrons and other collaborators at the end of the Miroir d'or de l'ame pecheresse of 1483 . See Claudin, 1:296-97, and Pellechet, who calls attention to the acrostic signatures of four publishers' names associated with the printing of Pierre d'Ailly's L'eschelle de penitance (Antoine Caillaut, Louis Martineau, Geoffroi de Marnef, and Belart). 
formed an integral part of the text, he omitted the rubrics that directed the reader to reconstruct them vertically. Le Noir obviously did not wish to draw attention to another printer and publisher. Remarkably, though, he modified the last lines of the Chasteau d'amours by replacing the eightverse acrostic of Gringore's name with two stanzas that spelled out his own. Furthermore, rubrics before each stanza alerted the reader to the presence of his first and last names (Figure 4.9): "Le nom de l'imprimeur trouverez par les lettres capitalles ... Le surnom" (You will find the name of the printer by the capital letters . . . The surname). Daring to appropriate Gringore's acrostic idea for his own ends, Le Noir also appropriated his very words. For he lifted at least four of the verses in his two-stanza acrostic from different locations in Gringore's text, combining together without regard for meaning in such a way that the two stanzas do not appear related to each other (Brown, "Confrontation," n. 25). An artificial relationship between vertical and horizontal meanings results, for this printer did not create verses from his name but tried to reconstruct an acrostic from existing lines. Le Noir, then, stole the author's words to form his own acrostic signature, which in the end replaced the true writer's name. This printer's dramatic assumption of the authorship of a work is translated by his appropriation of Gringore's moralistic first-person voice in the very opening lines of these artificially added stanzas, when he states: "Monstrer ay voulu que amour n'est que follie" (I wanted to show that love is only folly). Clearly Gringore would not have authorized Le Noir's attempt to insert himself into the poetic text, especially since his own name was dissociated from the work he had composed. Le Noir's onomastic manipulation reveals a conscious attempt on his part to mask the author's identity, give himself sole credit for the work, and wrest control of the Chasteau d'amours from Pigouchet and Vostre.$^{45}$ His unauthorized printing and appropriation of Gringore's Chasteau d'amours in December 1500 anticipated in fact his pirating adventures involving Lemaire's Temple d'honneur et de vertus, Bouchet's Regnars traversant, and La Vigne's Vergier d'honneur in 1504. But it also precipitated a very important reaction on the part of these writers, who dared to challenge such practices in the legal arena. It is possible that Gringore served as one of La Vigne's witnesses against Le Noir in the June 1504 lawsuit, as did Bouchet, whose acrostic signature in the stolen Regnars traversant provided the only proof of his authorship (see Figure 1.2).

Although Gringore's name did not always appear paratextually in the

45. Le Noir probably chose to appropriate this particular work because it had already been favorably received. In fact, he published a second edition of the Chasteau d'amours on February 4, 1501, N.S., which closely follows the edition of six weeks earlier, except that an error in his acrostic signature in the December 1500 edition has been corrected. 
A compaignie a folle fonme

Ia caule pour quop if fies bfo/me

ER que rbacum pout fon argene

pecket en culp eftorligent.

Eaufcune difent que fe bo:deau

Eommun eff etrébien os oonne

Et que dedene ceffuy cinateau

pat des fegiftes fut oonne

Eep faimifte artarfonne

Difta dicuen tegretz et pisuts

IL pete tous fes foinicateuto.

CDuis que dieu Bait paiffats putiets

Et que cbaftete ayme tant

Me foyons pas itregufters

Duidone du chaptrau tout Batant

Deu que fupute tout contant

Jf att gene en perfe ef chauffer

Et que en fil) fes meme en enfet.

CEe nom de fimpsimeut qui a ipsi me ce fiute cögnoiftes par fes pié

mietes fettres de ce couptet .

T. Drenez Biape amout natutelfe Inuocant feffence immostefle 5atdienne des poutes ames SDfant amour qui eft ctuefle Diflaine pfaine de stane BPa Imes Letciez les bertueules femmes Bontrufes doulces ampables

Fig. 4.8a. First 7 lines of Pigouchet's acrostic, from Le chasteau d'amours, 1st ed., B.N., Réserve Ye 1322, fol. $44^{r}$. (C) clichés Bibliothèque Nationale Paris. 


\section{Etrous ttounetes maintec bames}

IIte(Bonneftes et Bettuables.

\section{Tfe nom du marciant qui a fait faite ce liute.}

\section{(1) Setuez dicu principaftement} Jopeup (etes tant que autes bie A'ats Bous gatoes dirctetement 5iDu que Bous fopez nuffement Dapez deflus aufteup enupe.

TIE fumom dubit matchant. (IDous qui aymez ouftere taifoin) SBtemperez a la faifon 乌i ferez reputez tteffaiges Tant auez oup de Blar on ZRelpandu (ans nufle actioifon) Eitrooubte; peu fes paffaiges.

\section{If fe furnom de lacteut qui a fait et compofe ce fiute pat les piemier tce Petttes de ce couplet.}

(1. Bene de Bien quilifesce liute 3 ememosezen boz couraiges Treunefle qui maint a fault flute

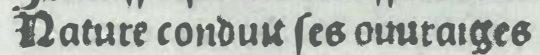
batdez touf iouts le dit bes faiges SD bemperes a leut tequefte 3iecorocs treflous cres paffaiges En folle amout peu on acquefte.

Fig. 4.8b. Pigouchet's (last 2 lines), Simon Vostre's, and Gringore's acrostics, fol. $44^{v}$. 


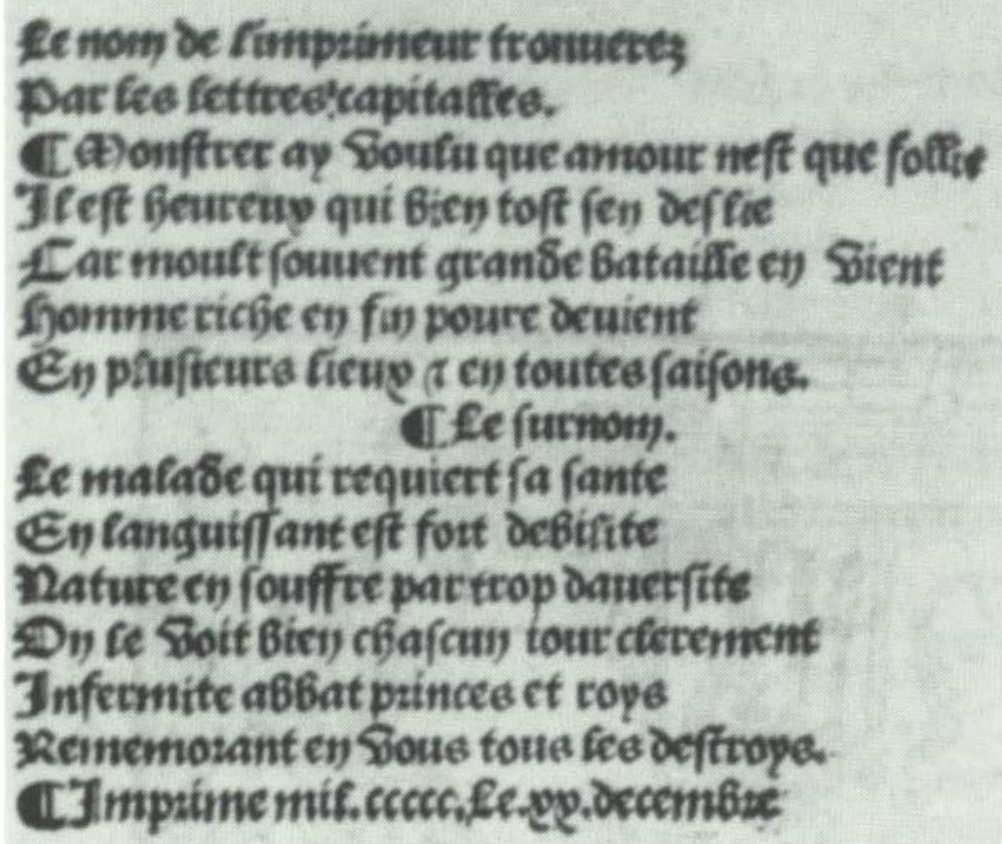

Fig. 4.9. Michel Le Noir's acrostic, from Le chasteau d'amours, 2 d ed., B.N., Réserve Ye 1019, fol. $34^{\mathrm{r}}$. (C) cliché Bibliothèque Nationale Paris.

works he himself subsequently published, ${ }^{46}$ in each of these and in fact in nearly all his other published writings, he signed with an acrostic stanza, whose ubiquity transformed it into a personal trademark much like the Mère Sotte woodcut (see my "Text," n. 39). As we discovered in the Chasteau de labour, the rubric "L'acteur" often set this final stanza apart from the rest of the verses in the text. Sometimes, however, more elaborate details direct the reader to look for the author's name or to reconstruct the vertical text containing his signature. The rubric "Le surnom de l'acteur sera trouvé par les premieres lettres de ce couplet" (The last name of the author will be found in the first letters of this stanza) announces the last stanza of the landmark Folles entreprises, whereas the Notables enseignemens offers these hints: "Fin et conclusion de ce present livre laquelle monstre et enseigne par la premiere lettre de chacun vers le surnom de l'acteur" (End and conclusion of this present book which

46. In some works, Pierre Gringore's name was announced either on the title page ( $\mathrm{La}$ chasse du cerf des cerfs; L'espoir de paix; Les heures de Nostre Dame; La paraphrase . . . Pseaumes) or in a colophon at the end (La complainte de Trop Tard Marié; Le jeu du Prince des Sotz; Les menus propos; Notables enseignemens). 
shows and indicates the last name of the author by the first letter of each verse). In La quenoulle one reads, "Incitation de l'acteur" (The Author's Incitation); in La complainte de la cité crestienne, "Conclusion de l'acteur" (The Author's Conclusion). The rubric "L'Acteur et surnom d'icel mys" (The Author and his last name placed herein) precedes the acrostic stanza in La chasse du cerf des cerfs. The timing of this change in signature rubrics suggests that they were motivated in part by Le Noir's alterations of Gringore's textual signature and, moreover, that they led to the author's acquisition of privileges and the decision to publish his own writings.

Unlike the more ambiguous metaphorical signatures characteristic of Molinet and La Vigne early in their careers, which risked greater anonymity once the text reached readers outside the literary circle that would have recognized them, Gringore's use of the acrostic, especially in its position of closure and in conjunction with a promotional rubric, reflects a growing concern to ensure that his authorship would be recognized and remain associated with the text. Gringore's textual signature-like Molinet's and La Vigne's eventually_-became more and more accessible, ensuring that his public would recognize his name. Even when Gringore finally succeeded in obtaining patronage in 1518, which ultimately led to the disappearance of his Mère Sotte woodcut, he continued to sign with his famous acrostic stanza. Although paratextual praise was accorded his new patron's name in the works Gringore had published while working under his aegis, the poet never incorporated the duke of Lorraine's acrostic within the text. Gringore's initial independence as a writer had established a pattern whereby his own name was the one that he consistently publicized in his editions. ${ }^{47}$

Jean Lemaire's method of self-identification in his works provides evidence of how printing was gradually becoming an integral part of the authorizing process by the early sixteenth century. Whereas Molinet, La Vigne, and Gringore had experienced the loss of their authorial identities by dint of publishers' manipulation of their signatures in different circumstances during the late fifteenth and early sixteenth centuries, Lemaire was spared the same misfortune. His appearance on the Parisian literary scene in 1504-at precisely the moment when La Vigne, Bouchet, and Gringore were legally challenging or about to challenge the misappropriation of their works and names by publishers-was timely indeed and may explain why Lemaire never adopted a textual signature.

47. See Chapter 3 above for a discussion of Gringore's dedication to the lord of Ferrières in the Folles entreprises; for the author's reference to Antoine de Lorraine in the fourth edition of the Fantasies de Mère Sotte, see Frautschi ed., 43. 


\section{Poets, Patrons, and Printers}

La Vigne's successful lawsuit, followed by Gringore's acquisition and advertisement of his own privilege a year later, served notice to publishers that writers had become aware of the need to play a more active role in the legal and practical appropriation of their works.

As we have seen, Lemaire often signed his writings with the device "De peu assez," which he placed outside the literary text. ${ }^{48}$ But he adopted another strategy for ensuring recognition of his authorship, one which suggests that the paratext of imprints could legitimately authorize a writer's work through the advertisement of his name, especially when that writer supervised the reproduction and distribution of those imprints. By making extended use of introductory épitres, as in the editions of his Temple d'honneur et de vertus (1504), Epitres de l'amant vert (published 1511), and Illustrations de Gaule et Singularitez de Troye (151124), and of prologues, as in his Concorde du genre humain (1508), Légende des Vénitiens (1509), Traicté de la différence des schismes et des conciles (1511), and Illustrations de Gaule, Lemaire provided a more stable context for those paratextual features which were often lost in the manuscript tradition or in the transition to print. Because they first appeared in print, not in manuscript form like Molinet's Art de rhétorique, and because the author participated in the publication of many of these works, Lemaire's prefatory material tended to remain attached to the texts with which they were originally associated once he took over initial control of their publication. While the author's continued pursuit of privileges for his works from 1509 on confirms his commitment to obtaining legal control over their reproduction and distribution, his choice of the paratext rather than the text as the site of self-identification announces the growing relevance of this signature space for promotion of the author's identity and image. It symbolizes as well the writer's withdrawal from the fictional dimension of his text. In the end, the struggle between authors and publishers for paratextual presence on title pages and in colophons, in presentation motifs and author-images, together with writers' attempts to maintain control over their texts through the use of more accessible signatures in the late fifteenth and early sixteenth centuries accompanied authors' appropriation of prefatory space in imprints.

With the problem of misappropriation intensifying or, rather, becoming legally acknowledged for the first time in the early sixteenth century, authors changed earlier patterns associated with the manuscript culture's more limited circulation of writing. They began to sign their works in a more self-conscious and defensive fashion, adopting both the acros-

48. Besides his Temple d'honneur et de vertus (1504), see Lemaire's Epitres de l'amant vert (1505; published 1511), Concorde des deux langages (1511; published 1513), the Illustrations de Gaule et Singularitez de Troye (Bks. 1-3), and Le traicté de la différence des schismes et des conciles de l'Eglise (1511). 


\section{Changing Authorial Signatures}

tic and the straightforward proper name. Lemaire's reliance on a paratextual signature prefigures the situation of Renaissance writers such as Clément Marot, whose first authorized edition of the Adolescence clémentine of 1534 exemplifies how, during the sixteenth century, prefatory material had developed into an integral part of authors' published works. ${ }^{49}$

Authors' use of more-straightforward signatures in early sixteenthcentury France was not just a sign of authorial self-consciousness and textual appropriation. Signatures had become marks of defiance as well, announcing a prise de position against unfair printing practices and the related misappropriation both of names and literary works. The inscription of one's signature into one's work was associated with the new artistic use of perspective and the so-called semiotic autonomy of the image (Lebensztejn, 46). Clearly the signature in a work, whether a painting or literary production, reflected the growing autonomy of the artistic creator in this period. How this new onomastic selfconsciousness was reshaped into textual expression will be the subject of the next chapter, in which I trace the movement of the more independent, self-aware author-figure from the frame or margins of his canvas into its very texture.

49. For a discussion of Renaissance prologues, see Jeanneret, 279-89. Genette, Seuils, 116-26, discusses the ambiguity of dedications as paratextual forms. 
